INVESTIGACIÓN 



\title{
O LAZER INFANTO-JUVENIL \\ NOS ESPAÇOS PÚBLICOS DE BARCELONA
}

\author{
EL OCIO INFANTO-JUVENIL \\ EN LOS ESPACIOS PÚBLICOS DE BARCELONA
}

CHILDREN'S AND PRETEENS

LEISURE IN BARCELONA'S PUBLIC SPACES

\section{Marcos Teodorico Pinheiro de Almeida, Lúcia Maria Gonçalves Siebra}

Universidade Federal do Ceará, Brasil

RESUMO: Sabe-se que é de grande importância ter espaços que promovam o resgate da cultura lúdica em grandes cidades da atualidade. As transformações das urbes ocorreram em consequência do desenvolvimento industrial, da urbanização e dos meios de comunicação, sendo responsáveis pela diminuição da transmissão da cultura lúdica entre crianças, adolescentes e adultos. $O$ propósito do estudo realizado em Barcelona foi de investigar como os usuários utilizam, se apropriam e escolhem os espaços públicos, destinados ou não ao lazer na cidade, em especial as praças públicas do bairro Vall d'Hebron. A investigação tentou compreender como estes espaços são organizados e, o mais importante, como as crianças e os pré-adolescentes percebem, utilizam e se apropriam dessas praças públicas como espaços para o lazer e o brincar. $\bigcirc$ artigo apresenta a análise de três espaços públicos, enquadrados na tipologia de praças públicas e que possuem diferentes características. Dentre as praças escolhidas para a investigação, duas se caracterizam como espaços planejados para o lazer e para o brincar (Praça 1: Jardines de Can Brasó e Praça 2: Josep Pallach) e a terceira, ainda que não projetada para estes fins, conta com considerável fluxo de usuários e atividades infanto-juvenis espontâneas (Praça 3: Joan Cornudella). O estudo de caráter qualitativo utilizou-se de observações não participantes e aplicação de questionários estruturados sobre a preferência de praças públicas e sobre o brincar, com sujeitos de 8 a 12 anos. Nas praças estudadas a população infanto-juvenil valoriza: os espaços mais amplos para brincar; os companheiros para brincar; situações lúdicas que potencializem suas competências motrizes; a duração do ato lúdico; espaços ou áreas para brincar com segurança e autonomia; o brincar como seus familiares (pai, mãe, avós, etc.) e outros adultos; as ações lúdicas espontâneas; a inclusão, diversidade e o pluralismo das diferentes manifestações lúdicas. 
RESUMEN: Sabemos que es muy importante contar con un espacio que proporcione el rescate de la cultura del juego en las grandes ciudades en la actualidad. Las transformaciones de la vida urbana se produjeron como consecuencia del desarrollo industrial, de la urbanización y de los medios de comunicación. Estos cambios fueron los responsables de la disminución de la transmisión de la cultura de juego entre los niños, adolescentes y adultos. El propósito del estudio realizado en Barcelona fue investigar cómo los usuarios utilizan, se apropiam y eligen los espacios públicos, sean destinados o no al ocio en la ciudad, en especial las plazas públicas del barrio de Vall d'Hebron. La investigación trató de entender cómo se organizan estos espacios, y lo más importante, cómo los niños y pre-adolescentes perciben, utilizan y se apropian de las plazas públicas como espacios para el ocio y el juego. El artículo presenta un análisis de los tres espacios públicos, enmarcados por la tipología de plazas públicas y que tienen diferentes características. Entre los espacios elegidos para la investigación, dos plazas se caracterizan por estar diseñadas para el ocio y para el juego (Plaza 1: Jardines de Can Brasó y Plaza 2: Josep Pallach); el tercer espacio, aunque no está diseñado para este fin, tiene un considerable flujo de actividades espontáneas entre niños y jóvenes (Plaza 3: Joan Cornudella). El estudio cualitativo consistió en la realización de observaciones no participantes y la aplicación de cuestionarios estructurados sobre la preferencia de las plazas públicas y sobre el jugar, a sujetos de entre 8 a 12 años. En las plazas del estudio la población infanto-juvenil valora: los espacios de juego amplios; la existencia de compañeros para jugar; situaciones lúdicas que mejoran sus habilidades motrices; la duración del acto lúdico; la seguridad de los espacios de juego así como la autonomía que fomentan; jugar con miembros de su familia (padre, madre, abuelos, etc.) y otros adultos; acciones lúdicas espontáneas; la inclusión, la diversidad y el pluralismo de los diferentes eventos recreativos.

PALABRAS CLAVE: Ocio; Jugar; Espacio Público.

ABSTRACT: We know that it is very important to have spaces which may promote play culture in large cities nowadays. Play culture has been decreasing as a result of industrial development, urbanization and the media and their impact on urban life. These changes were responsible for reducing the transmission of play culture among children, adolescents and adults. The purpose of the study in Barcelona was to investigate how people use, appropriate and choose public spaces for leisure in the city, particularly public squares in the Vall d'Hebron district. The research tried to understand how these spaces are organized, and most importantly, how children and preteens perceive, use and appropriate public squares for leisure and play. The article presents an analysis of three public spaces classified as public squares and their distinct characteristics. Two of these public squares were planned for leisure and for play (Square 1: Jardines de Can Brasó and Square 2: Josep Pallach) and the third, although not designed for this purpose, has considerable flow of users and spontaneous activities by children and pre-teens (Square 3: Joan Cornudella). The qualitative study used non-participant observations and structured questionnaires applied to 8-12 years-old respondents about their preference of public squares and spaces to play. The results show that children and preteens value: larger play spaces; mates to play; play situations that enhance their motor skills; the duration of the playful act; spaces or areas to play safely and autonomously; playing with their family members (father, mother, grandparents, etc..) and other adults; spontaneous playful actions; inclusion, diversity and plurality of recreational events.

KEYWORDS: Leisure; Play; Public Space. 


\section{Introdução}

Assim como as sociedades vem se transformando desde os primórdios até os dias atuais, o brincar também se transforma e se adapta aos novos contextos. A industrialização e a urbanização modificaram os costumes, a maneira de viver e até mesmo a estrutura familiar, contribuindo para que muitas atividades lúdicas não só se transformassem, mas até desaparecessem. Especialistas percebem esta mudança, chegando a afirmar que as crianças têm cada vez menos tempo e espaço para realizar e viver suas manifestações lúdicas e de lazer. Além disso, as famílias já não dispõem de tempo suficiente para estarem juntas, deixando de viver o que antes eram os momentos em família, favorecedores da aprendizagem lúdica.

A falta de espaços, a insegurança nos grandes centros urbanos e o acúmulo de atividades extracurriculares nas instituições educativas, entre outros fatores, tem banido gradativamente o lúdico das atividades infantis e juvenis nas escolas. As atividades de lazer dependem e sempre dependeram do convívio social, são aprendidas, não são atividades inatas, o lazer é uma aprendizagem social, de interação e de experimentação.

As transformações das urbes ocorreram em consequência do desenvolvimento industrial, da urbanização e dos meios de comunicação. Estas transformações foram responsáveis pela diminuição da transmissão da cultura lúdica entre crianças, adolescentes e adultos.

O propósito do estudo realizado em Barcelona foi de investigar como os usuários utilizam, se apropriam e escolhem os espaços públicos, destinados ou não ao lazer na cidade, em especial as praças públicas do bairro Vall d'Hebron. A investigação tentou compreender de que maneira as crianças e os préadolescentes utilizam as praças públicas como espaços para o lazer e o brincar.

O artigo apresenta a análise de três espaços públicos, enquadrados na tipologia de praças públicas, duas se caracterizam como espaços planejados para - lazer e para o brincar e a terceira, ainda que não projetada para estes fins, conta com considerável fluxo de usuários e atividades infanto-juvenis espontâneas.

\section{Introduction}

As societies has been transformed from the beginnings to the present day, the play also transforms and adapts to new contexts. The industrialization and urbanization changed customs, way of life and even family structure. This contributes to many recreational activities not only transforming but disappearing. Experts who perceived this change, went on to say that children have less time and space to perform and live their recreational and leisure events. In addition, families no longer have enough time to be together, losing the moments they had before as a family, prioritizing the playful learning times.

The lack of spaces, such as the insecurity in the major urban centers and the accumulation of extracurricular activities in educational institutions, among other factors, have gradually restricted the recreational activities of children and youth in schools. Leisure activities depend and always have depended on social interaction. These are learned, not innate activities; leisure is a social learning interaction and experimentation.

The transformations of the cities occurred as a result of industrial development, urbanization, and the media. These changes were responsible for the decreased transmission of play culture among children, adolescents and adults.

The purpose of the study in Barcelona was to investigate how people use, appropriate and choose public spaces for leisure in the city, particularly public squares in the Vall d'Hebron district. The research tried to understand how children and preteens use public squares as spaces for recreation and play.

The article presents an analysis of three public spaces, covered by the typology of public squares. Two are characterized as planned for leisure and for play and the third, though not designed for these purposes, has considerable flow of people and activities used spontaneous by children and youth. 


\section{Os Espaços Públicos como Estruturas de Lazer na Cidade}

A praça pública é um espaço adequado para realizar uma investigação científica, quando se trata de verificar experiências lúdicas significativas e observar a cultura do lazer. Pode funcionar como local estratégico para compreender a manifestação do brincar, além de possibilitar identificar como o público infanto-juvenil se apropria do mesmo.

Para Puig (2004) a educação para o lazer tem uma dupla missão de "educar no tempo livre" e "educar para o tempo livre". O lazer para Dumazedier (1994) e De Masi (2000) exerce nos dias atuais uma atração universal sobre todas as pessoas, em todas as idades e camadas sociais. Já para Rolim (1989, p.57) o "lazer torna-se atualmente um fenômeno universal. É uma força capaz de destruir ou de fazer desabrochar plenamente a pessoa humana". Aquilo que é aprendido através do lazer e da ludicidade traduz-se numa transferência de saberes, valores e atitudes que se fazem sentir no nível de qualidade de vida.

Os espaços públicos e privados se podem definir em diferentes perspectivas, urbanística, legal, psicológica, etc. Alguns aspectos são comuns nas muitas referências, por exemplo, a noção de que o espaço privado é algo que é de um (mesmo que este um seja composto por alguns) e, portanto, ele lhe dá o uso que queira desde que respeite as regras sociais. Por outro lado, o espaço público é o espaço de todos os cidadãos, de uma coletividade, sendo um espaço de uso comum de todos. Valera (1999), citado por Almeida \& Siebra (2008), comenta a clássica distinção de Zimring (1982) entre espaços privados e espaços públicos, abordando os conceitos como parte de um contínuo onde em um extremo está o espaço privado e no outro o espaço público. Como exemplo primeiro de espaço privado está o lar, no qual o controle da interação social está nas mãos de seu habitante. Como espaço público tem-se o exemplo da rua, onde o controle da interação social é difícil, ou mesmo impossível, por parte do cidadão, é um lugar completamente aberto à interação. As pessoas regulam o nível de interação que desejam nos seus espaços privados (com mais poder) e públicos (com menos poder).

Para os urbanistas, a importância do espaço público se dá na medida em que também organiza a

\section{The public spaces as structures in Leisure City}

The public square is appropriate to conduct a scientific investigation, when it comes to checking meaningful recreational experiences and observe the culture of leisure space. It can function as a strategic location to understand the manifestation of play, besides allowing to identify how the juvenile population appropriates the same.

According to Puig (2004) education for leisure has a dual mission "educating the free time" and "educating for free time". Leisure for Dumazedier (1994) and De Masi (2000) plays a universal appeal to all people in all ages and social strata. As for Ro$\lim (1989$, p.57) the "leisure now becomes a universal phenomenon. It is a force capable of destroying or fully blossoming human person". What is learned through leisure and playfulness translates into a transfer of knowledge, values and attitudes that are felt at a level of life quality.

Public and private spaces can be defined in different perspectives - urban, legal, psychological, etc. Some issues are common in many instances. For example, the notion that the private space is something that is for one (even if this one is composed of a few) and therefore it gives you the use you want provided it complies with social rules. On the other hand, the public space is the space of all citizens of a community, and is a space for the common use of all. Valera (1999), quoted in Almeida \& Siebra (2008), comments on the classic distinction that Zimring (1982) made between private space and public space, addressing the concepts as part of a continuum where at one extreme is the private space and the other is the public space. An example of private space is the home in which the control of social interaction is in the hands of its inhabitant. An example of a public space is the street, where the control of social interaction is difficult, or even impossible, for the citizen; it is completely an open space to the interaction. People regulate the level of interaction they want in their private spaces (with more power) and public (with less power).

For planners, organizing public space should be given importance for creating public access, pathways and spaces for the population expansion. The point of view about public spaces for- 
cidade criando acessos, vias e espaços de expansão para a população. O ponto de vista acerca dos espaços públicos formulado por Ildefons Cerdà (em sua teoria do urbanismo) postula que "toda cidade deve dotar-se de suficiente espaço público como para garantir seu desenvolvimento equilibrado. Evidentemente este espaço público deve estar suficientemente dotado de elementos de ornamentação que permitam uma melhora da paisagem urbana (fontes, relógios, quiosques, pontes, esculturas, etc.)" (Remesar, 1997, p. 14).

Cada cidadão, ao nascer ou viver em uma cidade, tem sua própria história pessoal entrelaçada com a da cidade, dotando os espaços, as ruas, os itinerários, etc. de significados que lhes são próprios. De acordo com Lynch (1998, p.9) “todo cidadão tem vínculos com uma ou outra parte de sua cidade, e sua imagem está embebida de lembranças e significados". Neste estudo focado na criança e no pré-adolescente, e em sua percepção do ambiente em que brincam, é importante compreender os espaços dentro de sua lógica e de seus desejos.

A praça e a rua ocupam espaços importantes na memória de cada um de nós, resgatando momentos, afetos, lembranças, sendo espaços de realizações sociais, de acontecimentos cotidianos e históricos, enfim, é onde a vida acontece de forma mais intensa e dinâmica, onde as pessoas se encontram e se reconhecem como parte integrante daquele espaço.

As mudanças urbanísticas, sociais, educacionais, econômicas e políticas ocorridas no passado até hoje, alteram significativamente a estrutura de vida familiar. Conforme relatam as autoras Gomes \& Gouvea (2008, p.49) “o século XIX se destaca como um período histórico de afirmação da vida social, da demarcação das fronteiras entre os espaços públicos e privados e dos sujeitos que os habitam". Nesse sentido, a prática lúdica precisa ser ampliada para espaços públicos, durante o tempo de lazer, promovendo uma relação entre pares e a apropriação de espaços possíveis para brincar.

No campo da pesquisa sobre crianças e pré-adolescentes, como em qualquer outro campo social, é preciso pontuar a história, "a memória" desses sujeitos na participação da construção da cultura e na organização dos sistemas sociais, Castro (2001) citado por Debortoli et al. (2008). mulated by lldefonso Cerdà (in his theory of urbanism) posits that "every city should provide themselves with sufficient public space as to ensure balanced development. Clearly this public space should be sufficiently endowed with ornamental elements that allow an improvement of the urban landscape (fountain, clocks, kiosks, bridges, sculptures, etc.) “(Remesar, 1997, p. 14).

From birth, each citizen who live in a city, have their own personal story intertwined with the city, providing spaces, streets, routes, and meaning that are appropriate to them. According to Lynch (1998, p.9) "every citizen has ties to one part or another part of their city, and his image is soaked in memories and meanings." This study focused on children and preteen, and its perception of the environment in which they play. It's important to understand the spaces within your logic and your desires.

The square and the street occupy important spaces in the memory of each of us. Redeeming moments, feelings, memories, being places of social achievements of everyday and historical events, is where life happens. The events are a more intense and dynamic form, where people meet and recognize themselves as part of that space.

The urban, social, educational, economic and political changes since the past until today, significantly alter the structure of family life. As the report from Gomes \& Gouvea (2008, p.49) writes "the nineteenth century stands out as a historic period of affirmation of social life, the border demarcation between public and private spaces and the subjects who inhabit them." In this sense, the playful practice needs to be extended to public spaces during leisure time, promoting a relationship between peers and the appropriation of possible places to play.

In research on children and preteens, as in any other social field, it is necessary to point out that the "memory" of these subjects participating in the construction of culture and organization of social systems, Castro (2001) cited by Debortoli et al. (2008).

Children and preteens seek to understand and signify the social order of adults, representing their world through play and leisure events. It is in the square and the street that playful and leisure time can make living with each an existing encounter and confrontation in the play. 
As crianças e pré-adolescentes buscam entender e significar a ordem social dos adultos, representando seu mundo por meio das manifestações lúdicas e de lazer. É na praça e na rua que o lúdico e o lazer tornam possível o convívio com o outro e com os demais, existindo o encontro e o confronto no brincar.

Segundo Retondar (2007) toda ação lúdica deve criar um espaço próprio, isto é, criar um espaço para brincar. Este espaço pode ser dentro de casa, na rua, na praça, terrenos baldios, escola, quadra esportiva, praia, piscina, mesa, jogo de tabuleiro, etc. O brincar acontece em um espaço singular e próprio, todo e qualquer espaço físico ocupado remete a sentidos simbólicos específicos.

O lugar de brincar é para Gutton (2013) um espaço de atividade, brincar é agir, brincar deixa uma marca dupla, no sujeito que brinca e no ambiente (espaço). Segundo Gutton (2013, p.249) o ato e a percepção de brincar estão inscritos no nível motriz, "o brinquedo, instrumento para brincar, está no espaço enquanto a brincadeira se desenvolve no tempo", afirma ainda que o brincar é uma atividade simbólica concreta e é responsável pela introdução da realidade entre o "simbólico e as fantasias" é onde o brincar tem um papel fundamental do Eu.

Para Santos (2013, p.75) devemos observar que existem diferentes elementos da composição lúdica que se repetem em vários contextos culturais “(...) as particularidades de cada espaço, considerando o ambiente como determinante das formas de brincar". A universalidade do lúdico pode acontecer em inúmeras comunidades do mundo e é o ambiente e materiais que determinarão as formas do lazer e do brincar.

\section{Metodologia}

Este artigo apresenta resultados de um estudo com características multidisciplinares e que encontra na Psicologia Ambiental e na Educação parte das opções metodológicas necessárias à análise da problemática.

Segundo Aragonés e Amérigo (1998, p.24) a Psicologia Ambiental é por definição "a disciplina que estuda as relações recíprocas entre a conduta das pessoas e o ambiente sócio-físico tanto natural quanto construído". Esta definição, em princípio,
According Retondar (2007) all playful action should create its own space, that is, create a space to play. This space can be at home, in the street, in the square, vacant lots, school, sports court, beach, pool table, board game, etc. The play takes place in a natural and proper place. All space and all physical footprint refers to specific symbolic meanings.

The place to play is, to Gutton (2013), a space of activity, playing is acting, that plays a dual brand, in the subject and in the environment (space). According Gutton (2013, p.249) the act and the perception of play are enrolled in a motor level, "the toy, a play instrument, is in space while the playing unfolds in time", further states that playing is a concrete and symbolic activity and is responsible for introducing the reality of the "symbolic and fantasies" where the play has a key role of the oneself.

For Santos (2013, p.75) we should note that there are different elements of playful composition that recur in various cultural contexts “(...) the characteristics of each area, considering the environment as a determinant of forms of play". The universality of the play can happen in many communities of the world and the environment and materials to determine the forms of leisure and play.

\section{Methodology}

This article presents the results of a multidisciplinary study. The methodological choices to analyze the problem are based in Environmental Psychology and Education Theories.

According to Aragonés e Amérigo (1998, p.24), Environmental Psychology by definition is "a discipline that studies the interrelationships between people's behavior and the socio-physical environment, both natural and built". This definition, in principle, guides the methodological choices in 
norteia as escolhas metodológicas neste trabalho, considerando que se trabalha em um ambiente sócio-físico, os espaços públicos da cidade, em especial as praças públicas, nas quais se observa o uso pela população, com destaque para o usuário infanto-juvenil.

A característica da Psicologia Ambiental denominada multimetodológica se pauta nas questões da interdisciplinaridade e amplitude de seus temas. "O que determina a escolha da metodologia (e, implicitamente, a escolha do local da pesquisa como campo ou laboratório) é o problema, e muitos deles se beneficiam com a utilização de uma pluralidade de métodos observacionais, experimentais e/ou entrevistas, entre outros" (Gunter e Rozestraten, 2005, pp.1-2).

Desta forma, a investigação se classifica como um estudo de caráter qualitativo (Bogdan, 1994; Maxwell, 1996; Neves, 1996; Maykut e Morehouse, 1999) e exploratório (Martins, 1994; Mattar, 1996), cuja estratégia metodológica escolhida foi o estudo de caso (Yin, 2001; Martínez Bonafé, 1990) do tipo descritivo-interpretativo (Merriam, 1988). A opção por uma investigação de caráter qualitativo se faz fundamental frente à necessidade de trabalhar dados descritivos que focam no brincar como parte da vida e do processo de educação do ser humano, sendo através dele que as crianças aprendem a cultura de um determinado contexto, se inserem nos grupos, resolvem problemas, enfim, conhecem o mundo que está ao seu redor, propiciando as condições para seu próprio desenvolvimento como ser único dentro de um mundo complexo.

Uma investigação do tipo exploratória pode fazer uso de diversos métodos de coleta de dados, sendo os principais: levantamento em fontes secundárias, fontes primárias, estudos de casos selecionados, aplicação de questionários, observação não participante e participante. Na observação, podem-se verificar os comportamentos e atividades realizadas nos espaços escolhidos com: anotações, gravação de declarações, fotografias, filmagens etc.

\subsection{Espaços Públicos}

O estudo se realiza na cidade de Barcelona que tendo sido cenário, a partir dos anos 80 do Século this work, considering working in a socio-physical environment. This applies to the city's public spaces, and especially public squares, in which we observe the use by the population, especially the juvenile user.

The characteristic of environmental psychology called multi-methodological is guided in matters of inter-disciplinarity and the breadth of its themes. "What determines the choice of methodology (and, implicitly, the choice of research site as field or lab) is the problem, and many of them will benefit from use of a plurality of observational, experimental and/or interview methods, among others" (Gunter and Rozestraten, 2005, pp.1-2).

Thus, this research is classified as a qualitative (Bogdan, 1994; Maxwell, 1996; Snow, 1996; Maykut and Morehouse, 1999) and exploratory study (Martins, 1994; Mattar, 1996), whose methodological strategy was the case study (Yin, 2001; Martínez Bonafé, 1990) as a descriptive and interpretive type (Merriam, 1988). The choice of a qualitative investigation becomes critical due to the necessity of working descriptive data that focus on playing as part of the life and of the education process of human. Through him children learn the culture of a given context, are included in groups, solve problems, and finally, know the world around you, providing the conditions for their own development as being unique within a complex world.

An exploratory investigation of the type that can make use of various methods of data collection, the main ones being: survey of secondary sources, primary sources, selected case studies, questionnaires, participant and non-participant observations. Through observation, one can verify the behaviors and activities in selected areas with: notes, recording of statements, photographs, filming etc.

\subsection{Public spaces}

The study takes place in the city of Barcelona that has been the scene from the 80 s of the twentieth 
$X X$, para muitos projetos de reabilitação, requalificação e construção de novos espaços públicos, principalmente parques, jardins e áreas verdes especialmente equipadas para uso da população (Busquets, 2004).

O bairro Vall d'Hebron (Distrito de Horta-Guinardó) se caracteriza por ter em sua área geográfica o maior índice de praças com áreas de jogos infantis.

A escolha dos espaços (área geográfica) para realização do estudo levou em consideração dois aspectos iniciais básicos: 1) Serem espaços públicos com características diferentes e, 2) Estarem situados no bairro Vall d'Hebron, que apresenta uma grande concentração de praças públicas para o lazer contando com equipamentos lúdicos. Assim, os espaços escolhidos para o estudo foram as praças públicas Jardines de Can Brasó, Joan Cornudella e Josep Pallach.

\subsection{Participantes}

A população, neste estudo, se classificou, de acordo com a literatura, como não probabilista do tipo intencional ou por julgamento. Segundo Martins (1994, p.41) considera-se amostragem intencional quando "de acordo com determinado critério, é eleito intencionalmente um grupo de elementos que irão compor a mostra. $\mathrm{O}$ investigador se dirige intencionalmente a grupos de elementos dos quais deseja saber a opinião".

O estudo foi aplicado em 42 usuários dos espaços públicos, compreendendo a faixa etária de 08 a 12 anos, de ambos os sexos. A aplicação dos questionários foi realizada na Escola Pau Casals, no bairro Vall d'Hebron, em Barcelona. Dados secundários demonstraram que os alunos da escola são na grande maioria moradores do bairro e usuários dos três espaços públicos participantes do estudo.

\subsection{Procedimentos}

Neste trabalho serão apresentados os procedimentos de observação não participante e aplicação de dois questionários estruturados, um sobre a preferência relativa às praças públicas do bairro e outro sobre o brincar propriamente dito. century with many projects for rehabilitation, upgrading and construction of new public spaces, especially parks, gardens and green areas specially equipped for use by the population (Busquets, 2004).

The Vall d'Hebron neighborhood (district of Horta-Guinardó) is characterized by having in its geographical area, the largest index of squares with areas of children's games.

The choice of spaces (geographic area) to conduct the study took into account two basic starting points: 1) they are public spaces with different characteristics, and 2) it is situated in Vall d'Hebron district, which has a large concentration of public squares to leisure counting on playground equipment. Thus, the spaces chosen for the study were public squares Jardines de Can Brasó, Joan Cornudella and Josep Pallach.

\subsection{Participants}

The population in this study was classified, according to the literature, not as probabilistic intentional or trial. According to Martins (1994, p.41) it was considered intentional when sampling "according to certain criteria, when intentionally chosen a group of elements that will make up the sample. The investigator intentionally directs the group of elements that you want to know the opinion."

The study was implemented in 42 of public spaces users, comprising the age group of 08-12 years old, of both sexes. The questionnaires were conducted in the Pau Casals School, on the Vall d'Hebron district in Barcelona. Secondary data showed that the students of the school are neighborhood residents and members of the three participating public spaces of the study.

\subsection{Procedures}

In this work, the procedures were non-participant observation and application of two structured questionnaires, one about preference of public squares in the neighborhood, and another on the play itself. 


\subsubsection{Observação não participante}

A investigação realizou observações não participantes utilizando registros descritivos e visuais (fotografias e filmagens) dos espaços e equipamentos existentes. As visitas técnicas foram realizadas nas praças em diferentes dias e horários nas quatro estações do ano (verão, outono, inverno e primavera).

\subsubsection{Pesquisa com questionário estruturado}

A proposta do estudo foi apresentada para a "Asociación de Madres y Padres (AMPA)" da "Escuela Pau Casals". Através da escola enviou-se aos pais/responsáveis um "Termo do Consentimento Livre e Esclarecido", o qual solicitava a autorização assinada pelo responsável para que cada criança e pré-adolescente participasse da investigação. Participaram alunos do segundo ao sexto ano (do ensino fundamental 1 e 2).

Neste trabalho serão apresentados os resultados obtidos na aplicação de dois questionários: 1. Preferência de Praça Pública para o Brincar; 2. Questionário sobre o Brincar.

O primeiro questionário era sobre preferências relativas às praças públicas nas quais cada sujeito gostava de brincar. O principal objetivo era identificar a preferência das crianças e pré-adolescentes acerca dos espaços lúdicos para o desenvolvimento de seu lazer e manifestações lúdicas. No questionário se apresentavam as três praças: Jardines de Can Brasó, Plaza Joan Cornudella e Josep Pallach. Abaixo do nome de cada praça existiam três imagens fotográficas que identificavam o referido espaço. Além de escolher uma praça preferida cada sujeito deveria justificar sua escolha de forma descritiva.

O segundo questionário era sobre o brincar e teve como objetivos identificar opções de escolha de espaços utilizados para brincar, frequência e horários de uso, importância atribuída ao brincar, companhias mais frequentes no brincar, preferência de jogos e brinquedos, e aspectos relacionados ao conceito de apropriação desses espaços lúdicos (Almeida, 2012).

\subsubsection{Non-participant observation}

Research was conducted using non-participant observations and visual descriptive records (photographs and footage) of existing spaces and equipments. Technical visits were made in the squares on different days and times in the four seasons (summer, autumn, winter and spring).

\subsubsection{Survey with structured questionnaire}

The study proposal was presented to the "Asociación de Madres y Padres (AMPA)" from the "Escuela Pau Casals'. The school sent parents/guardians a "Statement of Consent", which called for the authorization signed by the person responsible for each child and pre-teen (second to sixth grade) to participate in research.

This paper presents the results of applying two questionnaires: 1. Preference Public Square for Play; 2. Questionnaire on the play.

The first questionnaire was about preferences regarding public squares in which each subject enjoyed playing. The main objective was to identify the preference of children and preteens about spaces to play and development of their leisure and recreational events. The questionnaire is presented in three squares: Jardines de Can Brasó, Joan Cornudella and Josep Pallach. Below the name of each square were three photographic images that identified the aforementioned space. Besides choosing a preferred square each subject should justify your choice descriptively.

The second questionnaire was about the play activity and aimed to identify the choice of spaces used for play, frequency and times of use, the importance ascribed to the play, most frequent partners in play, choice of games and toys, and aspects related to appropriation of play areas (Almeida, 2012). 


\section{Resultados e Discussão}

Em primeiro lugar serão apresentados os resultados obtidos com a aplicação do questionário "Praça preferida para brincar" a partir dos espaços públicos definidos Plaza Jardines de Can Brasó, Plaza Joan Cornudella e Plaza Josep Pallach. Em segundo lugar serão apresentados os resultados obtidos com a aplicação do "Questionário sobre o brincar".

\subsection{Questionário praça preferida para brincar}

Tinha como proposta identificar entre as praças estudadas (Figura 1) aquela que a criança elegia como preferida para o desenvolvimento de atividades lúdicas e de lazer, além da justificativa apresentada por ela para esta preferência.

Figura 1. Imagens fotográficas utilizadas no questionário de escolha da praça preferida

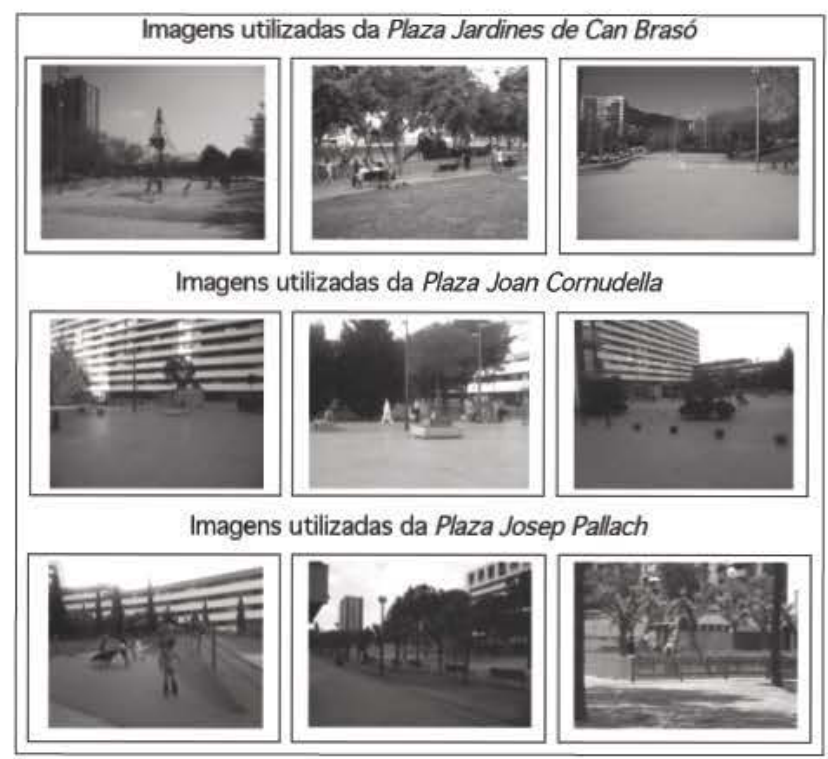

Fonte: Almeida, M.T.P., (2012).

A Praça Jardines de Can Brasó resultou como preferida pelos sujeitos participantes da pesquisa com $78 \%$ de frequência, conforme se pode observar na Figura 2. As Praças Josep Pallach e Joan Cornudella foram preferidas, respectivamente, por $14,3 \%$ e $7,1 \%$ dos sujeitos participantes.

As razões manifestadas pelos sujeitos para a preferência da Praça Jardines de Can Brasó foram organizadas em seis categorias a partir da análise de conteúdo dos discursos apresentados, podendo cada discurso apresentar mais de uma razão de preferência (Tabela 1).

\section{Results and discussion}

Firstly will be presented the results obtained from the questionnaire "Square preferred to play" considering the defined public spaces Jardines de Can Brasó, Josep Pallach and Joan Cornudella. Secondly will be presented the results obtained from the application of the "Questionnaire about play".

\subsection{Questionnaire about preferred square to play}

The proposal was to identify between the squares studied (Figure 1) the one that the child prefer for the development of recreational and leisure activities, in addition to reason given by her for this preference.

Figure 1. Photographic images used in the instrument of preferred square

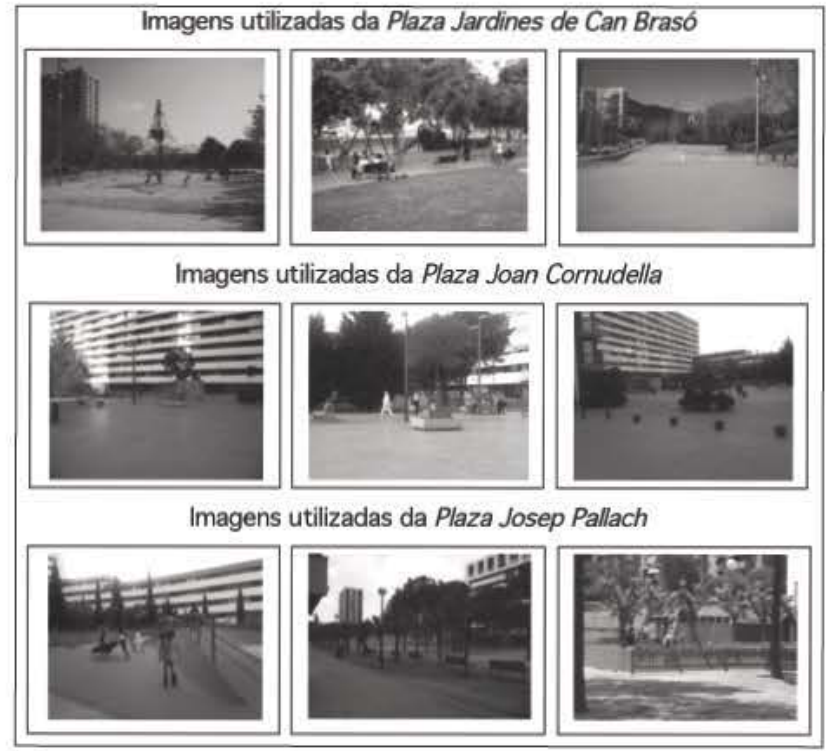

Source: Almeida, M.T.P. (2012)

The Jardines de Can Brasó Square resulted as preferred by the subjects in the research with $78 \%$ frequency, as can be seen in Figure 2. Josep Pallach and Joan Cornudella Squares were preferred respectively by $14.3 \%$ and $7.1 \%$ of participating subjects.

The reasons expressed by the subjects to the preference of the Jardines de Can Brasó Square were organized into six categories from content analysis of the speeches presented, and each speech can submit more than one reason of preference ( $\mathrm{Ta}$ ble 1). 
Figura 2. Praça preferida para desenvolvimento de atividades lúdicas e de lazer

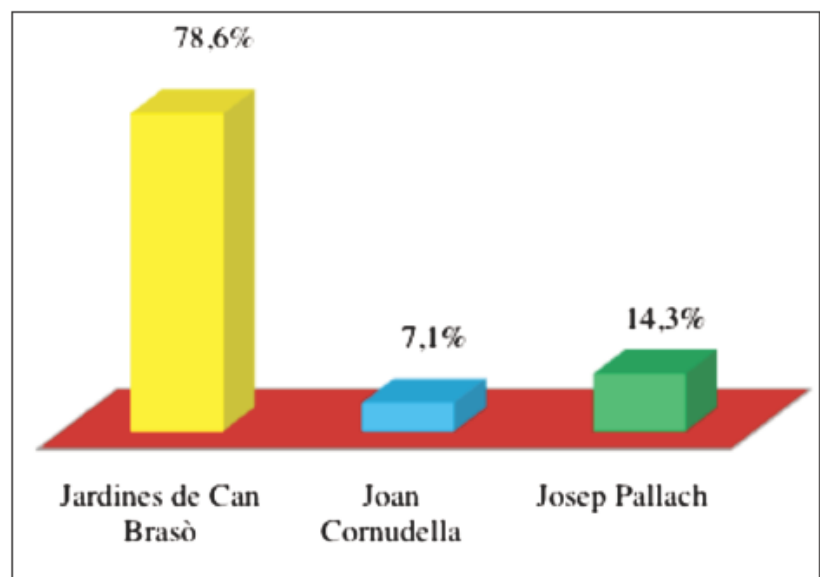

Fonte: Almeida, M.T.P., (2012).

As principais categorias presentes foram: 1. Atividades Lúdicas Motrizes; 2. Relação de Companheirismo; 3. Características do Espaço Físico; 4. Sentimentos Percebidos; 5. Objetos Lúdicos; 6. Equipamentos de Lazer.

A Praça Jardines de Can Brasó se apresenta para os sujeitos como um espaço público que garante as condições necessárias ao desenvolvimento pleno de atividades lúdicas motrizes como jogar (15), brincar (8), correr (5), escalar (3), jogar futebol (3), pegapega (2), conversar (2) e ainda, balançar, patinar, etc. A relação de companheirismo pode ser identificada nos discursos a partir das referências aos amigos (19), irmãos (3), crianças (3), outros (2). As principais características do espaço físico que impactam na preferência da praça foram seu grande tamanho (7) e dispor de mais espaços (7), localização de proximidade (2), além de ser bonita, melhor, ter dois parques, muitas coisas e vegetação, todos com uma

Tabela 1. Razões de Preferência da Praça Jardines de Can Brasó

\begin{tabular}{lcc}
\hline Categoria & Frequência & $\%$ \\
\hline Atividades Lúdicas Motrizes & 44 & 32,6 \\
\hline Relação de Companheirismo & 27 & 20,0 \\
\hline Características do Espaço Físico & 21 & 15,6 \\
\hline Sentimentos Percebidos & 17 & 12,6 \\
\hline Objetos Lúdicos & 14 & 10,4 \\
\hline Equipamentos de Lazer & 12 & 8,8 \\
\hline Total & 135 & 100 \\
\hline
\end{tabular}

Figure 2. Praça preferida para desenvolvimento de atividades lúdicas e de lazer

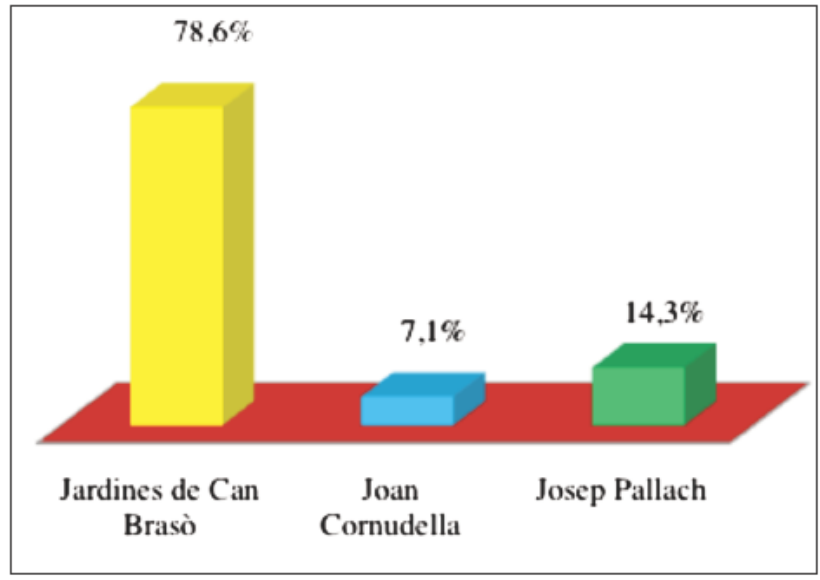

Source: Almeida, M.T.P., (2012).

Digite um texto ou endereço de um site ou traduza um documento.

The main categories present: 1. Motor Skills Activities; 2. Relationship Fellowships; 3. Characteristics of the Physical Space; 4. Perceived Feelings; 5. Toys; 6. Equipment Leisure.

The Jardines de Can Brasó Square presents to the subjects as a public space that ensures the full development of motor skills activities like: playing (15), fun (8), running (5), climbing (3), playing soccer (3), tag (2), talking (2) and swinging, skating, etc. The relationship of companionship can be identified in speeches from references to friends (19), brothers (3) children (3), other (2). The key features of the physical space that impact on the preference of the square were its large size (7) and have more spaces (7), location proximity (2), besides being beautiful, better, have two parks, lots of vegetation all with a reference. The perceived and manifested feelings

Table 1. Reasons for Preference of Jardines de Can Brasó Square

\begin{tabular}{lcc}
\hline Category & Frequency & $\%$ \\
\hline Motor Skills Activities & 44 & 32,6 \\
\hline Relationship Fellowships & 27 & 20,0 \\
\hline Characteristics of Physical Space & 21 & 15,6 \\
\hline Perceived feelings & 17 & 12,6 \\
\hline Toys & 14 & 10,4 \\
\hline Leisure equipment & 12 & 8,8 \\
\hline Total & 135 & 100 \\
\hline
\end{tabular}


referência. Os sentimentos percebidos e manifestados nos discursos foram identificados a partir de palavras como divertida, diverte-se, diversão (7), aproveitar (3), agradabilidade (2), e ainda, liberdade, gosto, encontro, conhecido, legal, com uma referência cada uma. Os principais objetos lúdicos nomeados foram patins (4), bicicleta (3), skate (3), além de brinquedos, jogos, patinete, bola, cada um com uma referência. Os equipamentos de lazer mais citados foram: teia/pirâmide (5), rampas (3), balanço (2), barco (1), golfinho (1).

\subsection{Questionário sobre o brincar}

Tinha como proposta identificar os espaços preferidos pelos usuários, em cada uma das praças estudadas, para realizar as atividades lúdicas. Além disso, buscou relacionar os jogos e brinquedos preferidos para uso no espaço público e as diversas formas de interação no desenvolvimento da atividade lúdica.

3.2.1. Sobre os espaços preferidos para brincar nas praças estudadas

Sobre o tema dos espaços da praça que os usuários mais gostam de utilizar, encontram-se os lugares preferidos em cada uma delas.

Na praça Jardines de Can Brasó o lugar preferido com $81,5 \%$ é o espaço lateral da praça no qual encontra-se uma longa rampa que desce até o parque do barco. Neste espaço as atividades mais desenvolvidas são andar de bicicleta, patins, patinetes e skate. No espaço central da Praça Jardines de Can Brasó, com 66,7\% está localizada a rampa pequena e o centro da praça onde fica um grande espaço quadrado que as crianças usam para jogar futebol, pega-pega, corrida, andar de bicicleta, jogar vôlei e outras atividades lúdicas.

$\mathrm{Na}$ Praça Joan Cornudella os espaços centrais com $57 \%$ de preferência cada um, concentravam as atividades, bancos, sendo caracterizados por grande amplitude.

$\mathrm{Na}$ Praça Josep Pallach o espaço central de chão batido com árvores e duas tabelas de basquete foi o principal espaço preferido com $75 \%$ de frequência, também preferidos os espaços: lateral com superfície plana, longo e cimentado, e o espaço mais in speeches were identified from words like laughs, fun (7), enjoy (3), pleasantness (2), and yet, freedom, love, meeting, known, nice, each with one reference. The main recreational objects named were skates (4), cycling (3), skateboarding (3), as well as toys, games, scooter ball, each with a reference. The most cited entertainment equipment were: web/pyramid (5), ramps (3), swing (2), boat (1), dolphin (1).

\subsection{Questionnaire about play}

The proposal was to identify favorite spaces to perform recreational activities on each square. In addition, we sought to relate favorite toys and games for use in the public space and the various forms of interaction in the development of playful activity.

3.2.1. About the preferred places to play in the squares studied

In the Jardines de Can Brasó Square, the preferred place is the lateral area of the square on which lies a long ramp leading down to the park where is the boat, with $81.5 \%$. In this space the most common activities are biking, skate, scooter and skateboard. In the central area of Jardines de Can Brasó Square, with 66.7\%, is located the small ramp and center of the square, with a large space that children use to play soccer, tag, running, biking, volleyball and other recreational activities. Joan Cornudella Square has two central areas characterized by large amplitude and focused activities and banks, with 57\% preference each one.

Josep Pallach Square, in its central area with beaten ground and trees and two basketball hoops, being the main favorite space with $75 \%$ frequency. Also additional preferred spaces included: sidewalks, long and cemented surface, and the larger space with hard standing area and side seats, both with $62.5 \%$ frequency.

It was evident in this study that the wider spaces of the squares are the favorites to play, mainly because they allow the motor skills games, be they individual or collective. 
amplo com área cimentada e bancos laterais, ambos com 62,5\% de frequência.

Ficou evidente neste estudo que os espaços mais amplos das praças são os favoritos para brincar, principalmente porque possibilitam os jogos motrizes, sejam eles individuais ou coletivos.

3.2.2. Sobre os jogos e brinquedos preferidos para o desenvolvimento da ação lúdica e de lazer nas praças públicas estudadas

\section{Praça Jardines de Can Brasó}

Como se pode observar na Figura 3 os jogos de correr, saltar, deslocar, ou seja, aqueles onde as habilidades motrizes estavam presentes, foram os preferidos dos sujeitos, entre eles, o "Jogar futebol" e "Jogar pega-pega" com 13,7\%, cada um. Os jogos e as brincadeiras que utilizavam equipamentos lúdicos como a "bicicleta e patins" com 7,4\% e 6,3\%, respectivamente. Brincadeiras como: brincar de esconde-esconde, pular corda, jogar taco ou Bets e jogar pega-pega na pirâmide obtiveram cada uma 5,3\% da preferência. Com 6,3\% temos uma modalidade esportiva que eles gostam muito de vivenciar na praça que é o "Jogar vôlei" onde meninas e meninos utilizam o espaço mais central da praça. As rampas existentes na praça eram os lugares preferidos para andar de patins $(6,3 \%)$, skate $(3,2 \%)$ e patinete $(1,1 \%)$.

Os jogos e as brincadeiras preferidas na questão anterior determinam os brinquedos preferidos das crianças para brincar na Praça Jardines de Can Brasó.

Apresenta-se na Figura 4 os brinquedos que induzem ao ato motriz e que têm a grande preferência dos respondentes. Com 20,5\% a "bola de futebol" para jogar, é utilizada por ambos os sexos, sendo comum a prática conjunta. A "bicicleta e os patins", ambos com $20,5 \%$ de preferência, eram os materiais lúdicos da categoria de brinquedos móveis com rodas mais utilizados.

Ainda na categoria de brinquedos móveis com rodas o "Patinete" e o "Skate" conquistavam 8,4\% cada um na preferência das crianças. Um fato interessante que não deve ser desconsiderado é o uso de brinquedos como: Nitendo DS $(2,4 \%)$ e PSP $(1,2 \%)$, estas novas gerações tecnológicas de jogos
3.2.2. About games and favorite toys for the development of recreational and leisure activity in the studied public squares

\section{Jardines de Can Brasó Square}

As seen in Figure 3 the games that run, jump, move, those where the motor skills were present, were the preferred, among them the "Play soccer" and "tag" with 13 7\% each. Games and play that used recreational equipment such as "bikes and skates" with $7.4 \%$ and $6.3 \%$, respectively. Games like: playing hide and seek, jump rope, play cricket/bets and play tag in the pyramid gained 5.3\% each preference. 6.3\% loves to "play volleyball" in the square, girls and boys use the more central area of the square to that. Existing ramps in the square were the preferred places for skates (6.3\%), skateboard (3.2\%) and scooter (1.1\%).

Play and favorite games on the previous question determine the children's favorite toys to play with in the Jardines de Can Brasó Square.

Is presented in Figure 4 toys that induce motor act and have a great preference of respondents. $20.5 \%$ preferred "soccer ball" to play and is used by both sexes, being common in joint practice. "Bikes and skates," both with $20.5 \%$ were the category of mobile wheeled toys over used.

Still in the category of mobile wheeled toys such as the "Scooter" and "Skateboard" conquered 8.4\% each in the preference of the children. An interesting fact that should not be overlooked is the use of toys as: Nintendo DS (2.4\%) and PSP (1.2\%), these new generations of technological games and toys are increasingly taking part in children's lives in all areas, including the public square. 
Figura 3. Jogos e brincadeiras: Jardines de Can Brasó

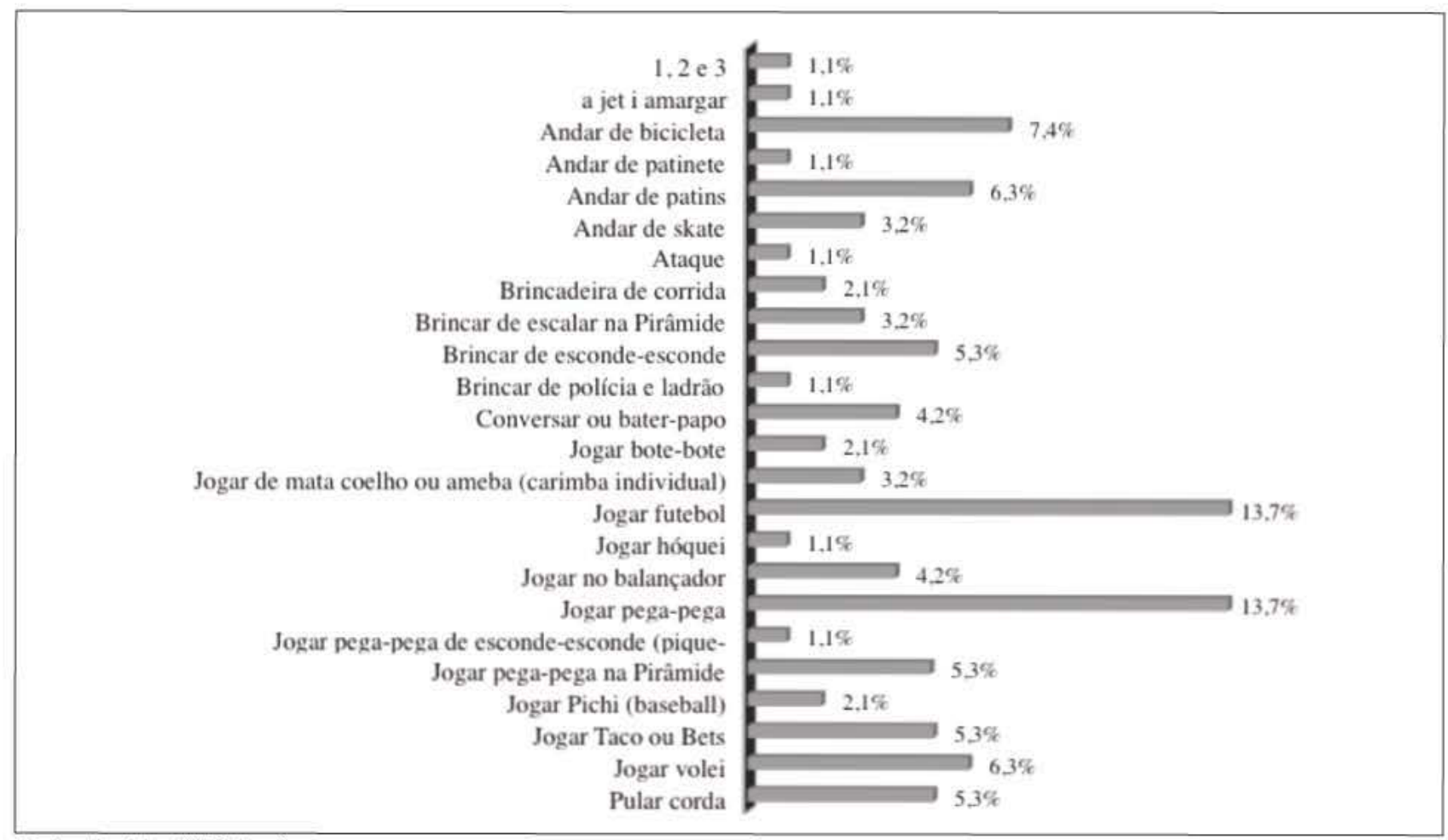

Fonte: Almeida, M.T.P., (2012).

Figure 3. Games and Play: Jardines de Can Brasó Square

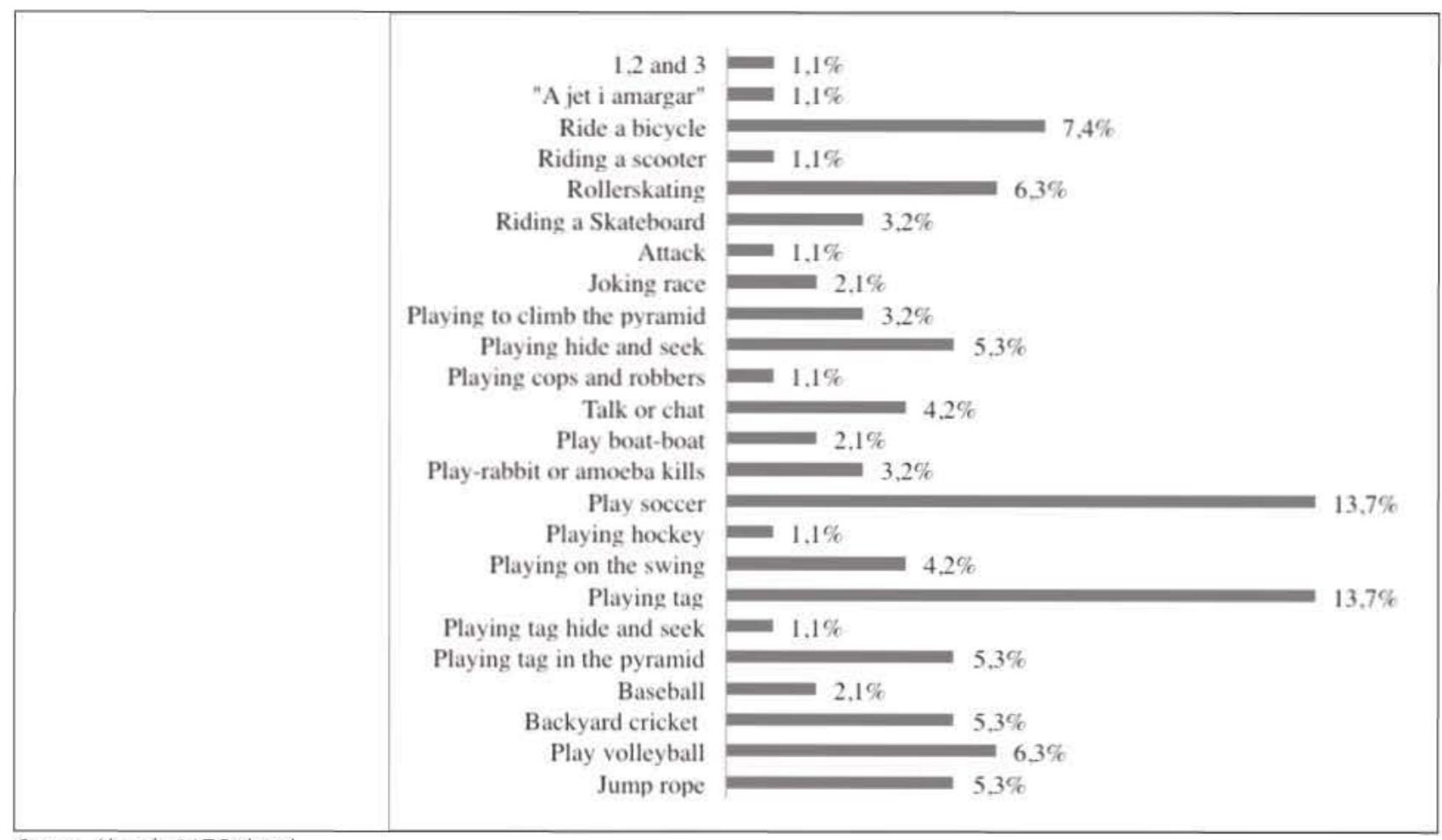

Source: Almeida, M.T.P., (2012). 
e brinquedos estão cada vez mais fazendo parte na vida da criança em todos os espaços, incluindo a praça pública.

Figura 4. Brinquedos: Praça Jardines de Can Brasó

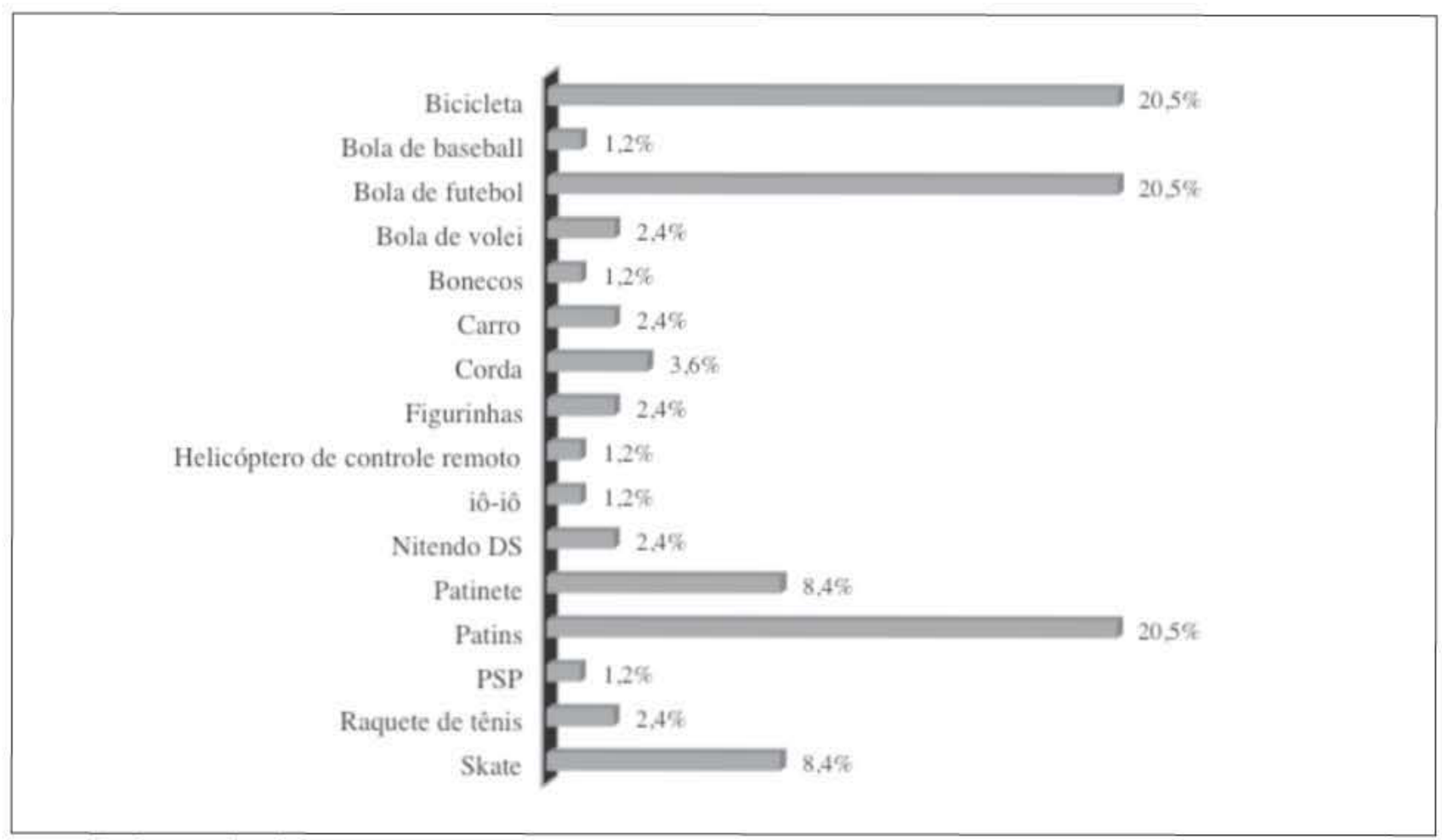

Fonte: Almeida, M.T.P., (2012).

Figure 4. Toys: Jardines de Can Brasó Square

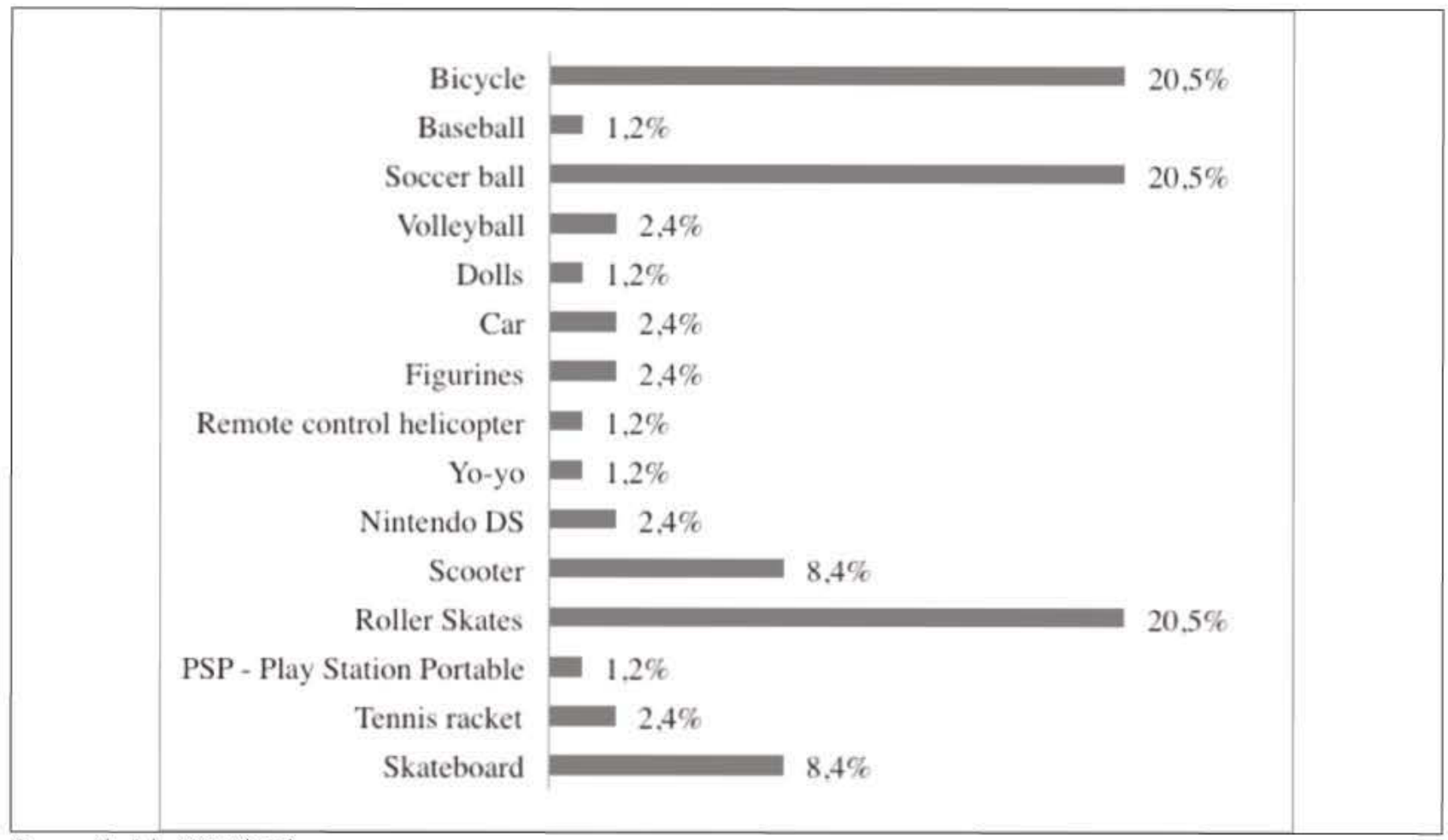

Source: Almeida, M.T.P., (2012). 
Figura 5. Jogos e brincadeiras: Praça Joan Cornudella

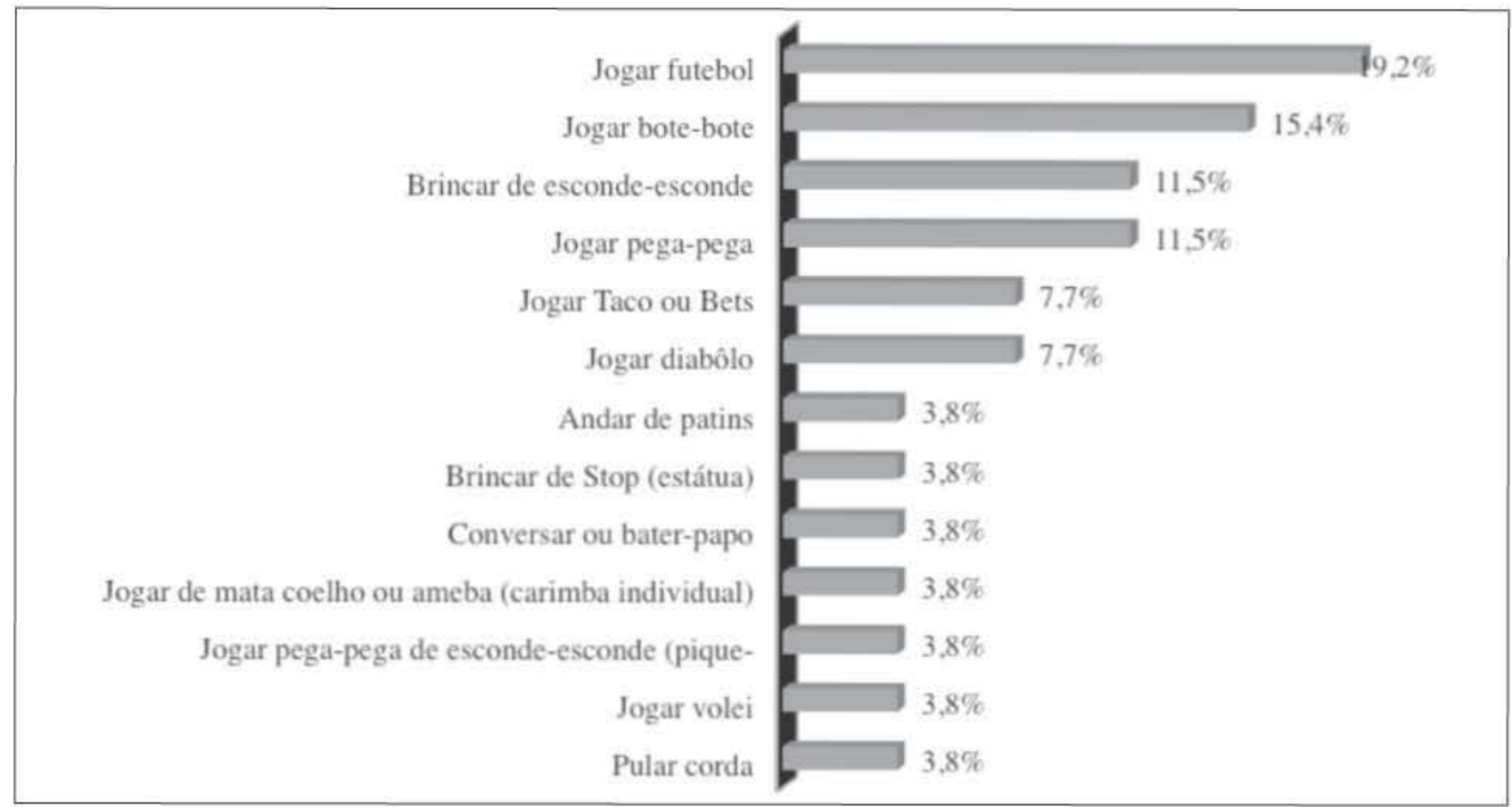

Fonte: Almeida, M.T.P., (2012).

Figure 5. Brinquedos: Praça Jardines de Can Brasó

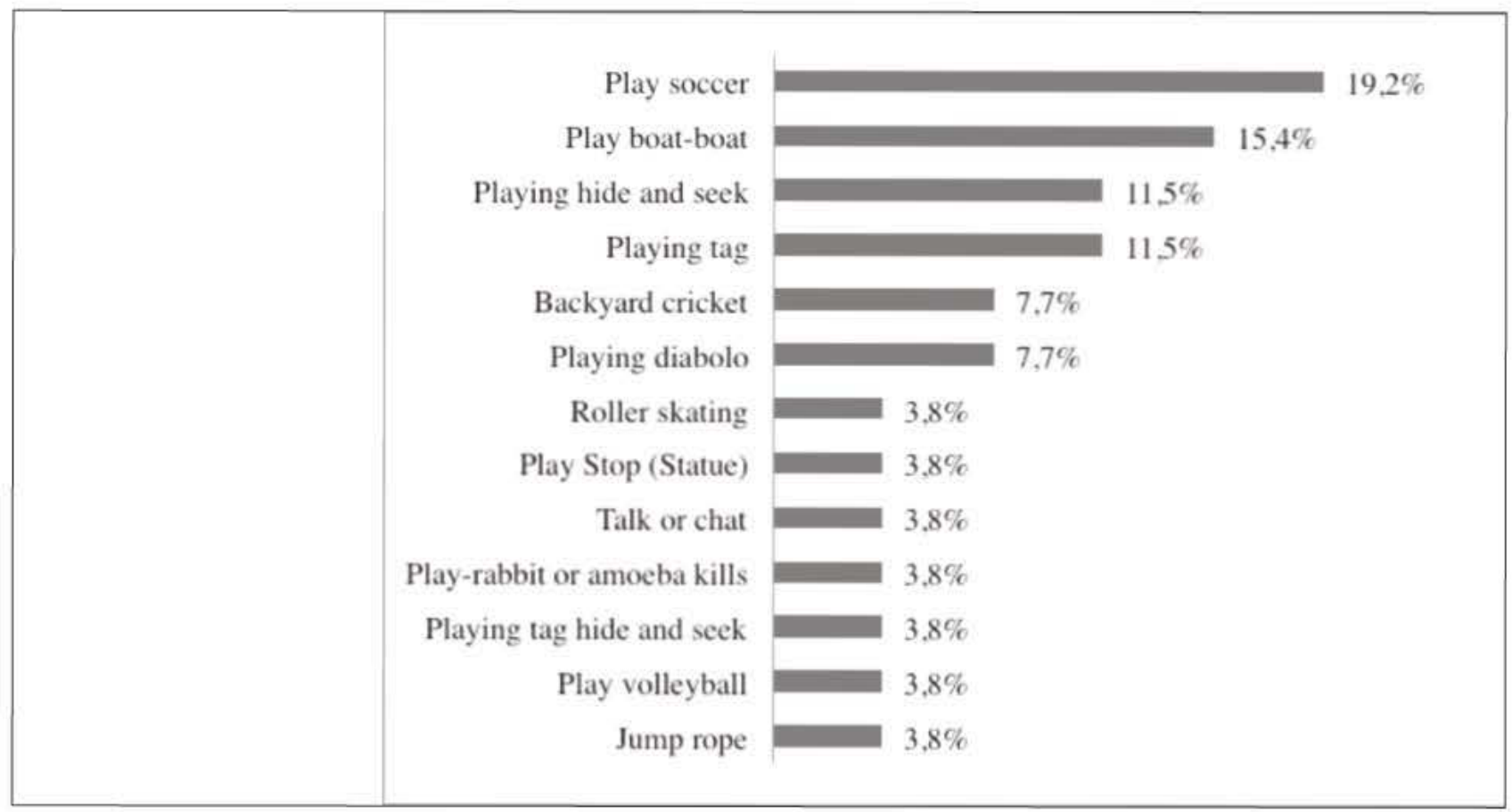

Source: Almeida, M.T.P, (2012) 
A Figura 5 apresenta os resultados relativos aos jogos e brincadeiras preferidos pelos usuários na Praça Joan Cornudella, o "Jogar futebol" confirma a preferência dos usuários com 19,2\%. Em segundo lugar na preferência dos respondentes encontra-se "Jogar bote-bote" com 15,4\%. Brincar de "esconde-esconde" e de "pega-pega" tiveram 11,5\% das respostas. Os jogos tradicionais "Jogar taco" e "Diabôlo" receberam $7,7 \%$ da preferência. Com 3,8\% os jogos espontâneos (tradicionais e pré-desportivos) como: andar de patins, stop (estátua), mata coelho ou carimba, pique esconde, pular corda, vôlei e ainda, algumas crianças colocaram a atividade de conversar ou bater-papo como um ato lúdico.

Quanto ao tema dos brinquedos preferidos das crianças, conforme se pode observar na Figura 6, a bola de futebol ficou com 21,1\% é também o brinquedo preferido na preferência das crianças da Praça Joan Cornudella. Como segundo lugar na preferência ficaram os "Patins" com 15,8\% e em terceiro lugar ficaram os seguintes brinquedos, diabôlo, patinete e taco com 10,5\% nas preferências dos respondentes. Os brinquedos estruturados como: bola de basquete, bicicleta, avião e helicóptero de controle remoto (brinquedos eletrônicos) e os brinquedos não estruturados: corda e lenço tiveram $5,5 \%$ cada um na preferência das crianças.

\section{Praça Josep Pallach}

Como se observa na Figura 7, "Jogar futebol" é o jogo favorito dos usuários com 19,2\%. Em segundo lugar tem-se "jogar basquete" com 15,4\%. É importante salientar que a Praça Josep Pallach é a única das três praças onde existe um espaço para jogar basquete com uma tabela. Com 7,7\% de preferência ficaram: "andar de patins", "jogar vôlei", "jogar bote-bote" e "pega-pega". Nos jogos como: andar de skate, esconde-esconde, jogar boliche (bolos), mata coelho ou carimba, jogar tênis e pular corda, cada um obteve $3,8 \%$ na preferência das crianças.

Também constatamos na Praça Josep Pallach, conforme se pode observar na Figura 8, que a bola de futebol continua sendo o brinquedo preferido das crianças com 26,1\% da preferência. Em segundo lugar, encontram-se os "patins" com 17,4\%

\section{Joan Cornudella Square}

Figure 5 shows the results for play and favorite games by users on the Joan Cornudella Square, "Playing soccer" confirms the preference of the users with $19.2 \%$. Second in the preference of respondents "Play boat-boat " with $15.4 \%$. "Play hide and seek" and "tag" had 11.5\% of the responses. Traditional games like "Play cricket/bets" and "Diabolo" received $7.7 \%$ of the preference. With the $3.8 \%$ (traditional and pre-sports) spontaneous games like: skating, stop (statue), kills rabbit or stamping, pike hiding, jump rope, volleyball and even some placed a chat activity as a playful act.

On the subject of children's favorite toys, as can be seen in Figure 6, soccer ball got 21.1\% and is also a favorite toy in children's preference in Joan Cornudella Square. As second in preference were the "skates" with $15.8 \%$ and in third place were the following toys, diabolo, scooter and mace/bat with $10.5 \%$ in the preferences of the respondents. Toys structured as: basketballs, bikes, planes and remote control helicopters (electronic toys) and unstructured toys, skipping ropes and scarf were 5.5\% each in the preference of the children.

\section{Josep Pallach Square}

As shown in Figure 7, "Soccer" is the favorite game with $19.2 \%$. Second up is "basketball" with $15.4 \%$. Josep Pallach Square is the only of the three squares where there is a space to play basketball with a table. "Skating", "volleyball", "boat-boat" and "tag" with $7.7 \%$ of preference each one. In games such as skateboarding, hide and seek, bowling, kills rabbit or stamps, playing tennis and jumping rope, each with $3.8 \%$ on the preference of the children.

Also found in Josep Pallach Square, as can be seen in Figure 8 that the soccer ball remains the favorite toy of children with $26.1 \%$ of the preference. Secondly, there is the "skates" $17.4 \%$ and then the bicycle at 13\%. Toys "skipping rope", "Nintendo DS" and "skateboard" had $8.7 \%$ in preference, while toys such as, basketball, MP4, scooters and rackets ob- 
Figura 6. Brinquedos: Praça Joan Cornudella

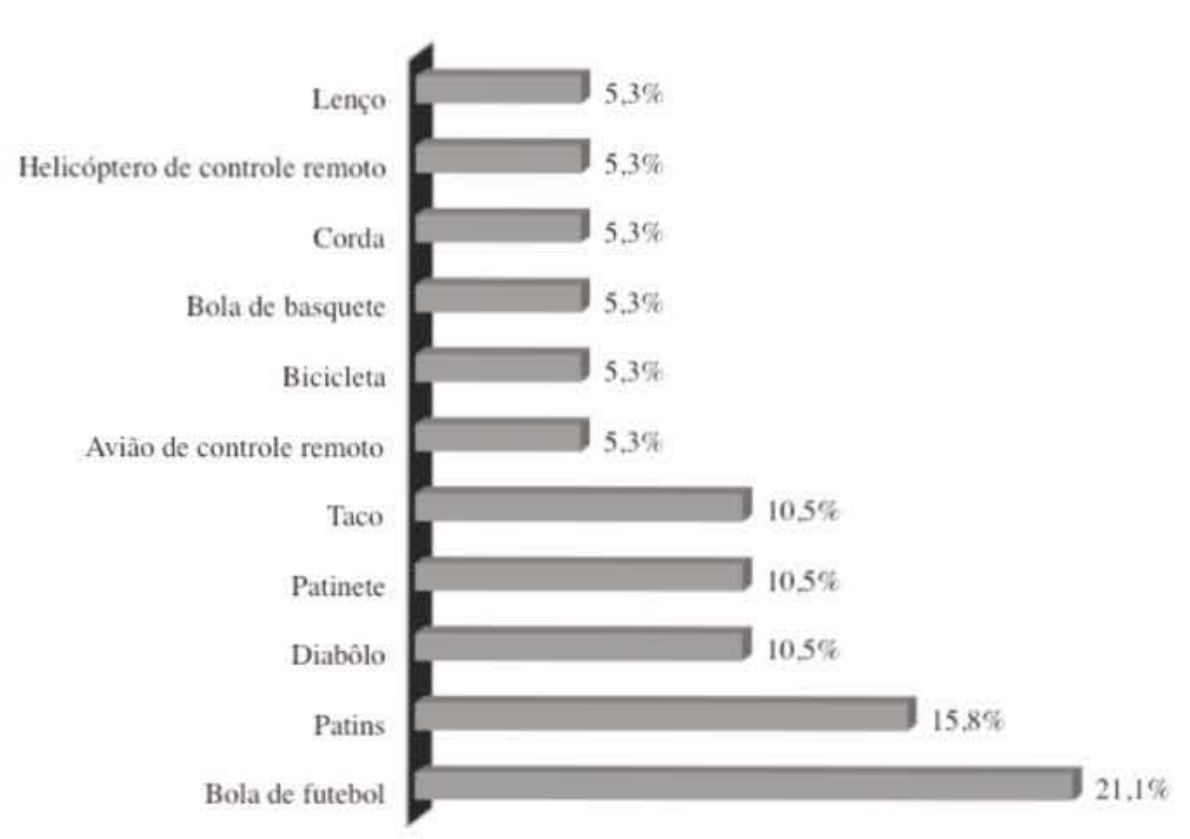

Fonte: Almeida, M.T.P., (2012).

Figure 6. Toys: Joan Cornudella Square

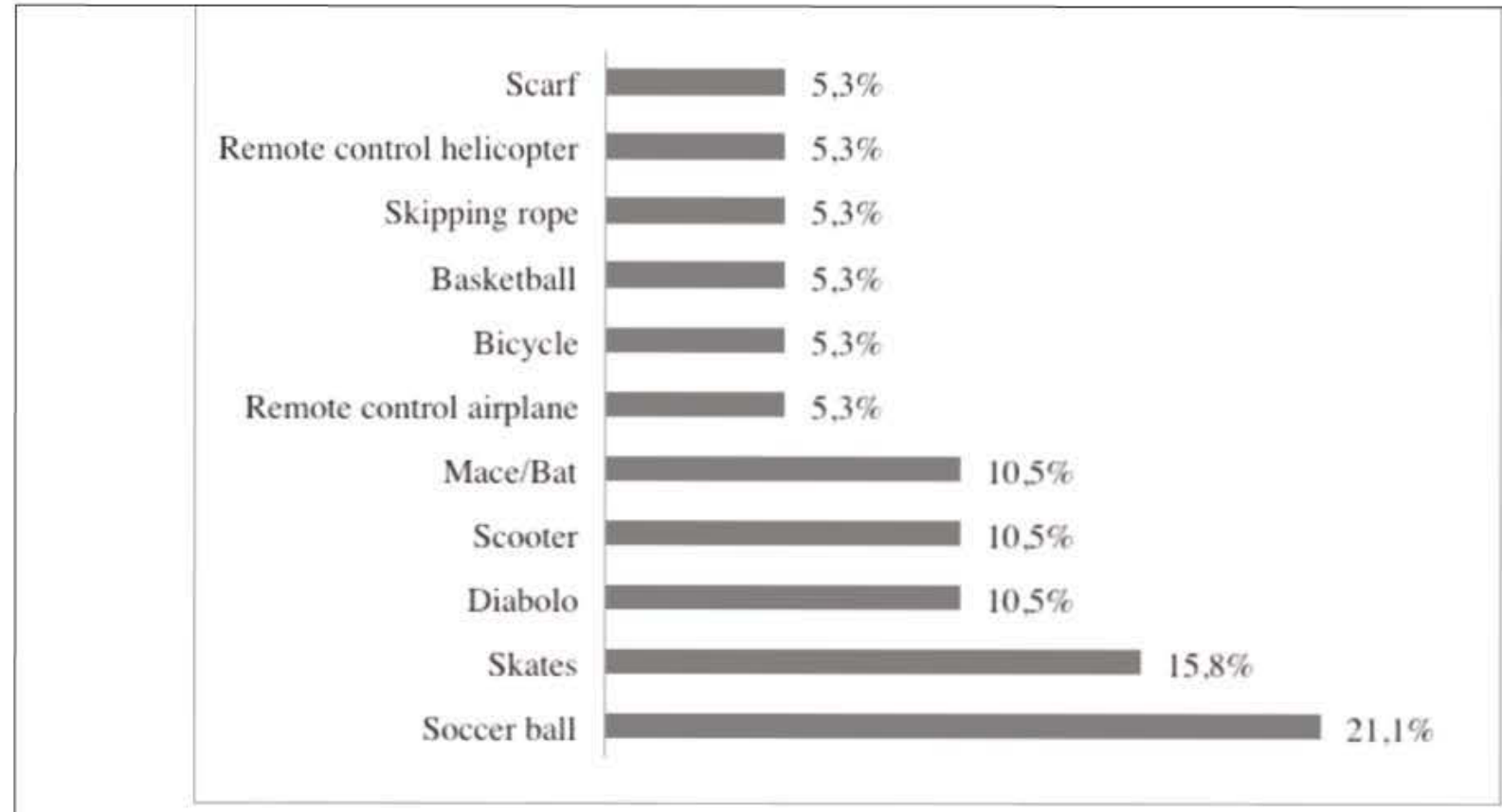

Source: Almeida, M.T.P., (2012).

e, em seguida, a bicicleta com $13 \%$. Os brinquedos "corda", "Nitendo DS" e "skate" tiveram 8,7\% nos resultados de preferência, enquanto que os brinquedos, bola de basquete, MP4, patinete e raquete de tênis obtiveram cada um $4,3 \%$ na preferência dos usuários. O MP4 e o Nitendo DS são tained $4.3 \%$ each one on preference users. The MP4 and the Nintendo DS are more current options of electronic equipment or electronic toys, and references for a more technological design in children's lives. It was quite common in the observation phase, see children, youth and adults with their laptops, video games, etc. 
Figura 7. Jogos e brincadeiras: Praça Josep Pallach

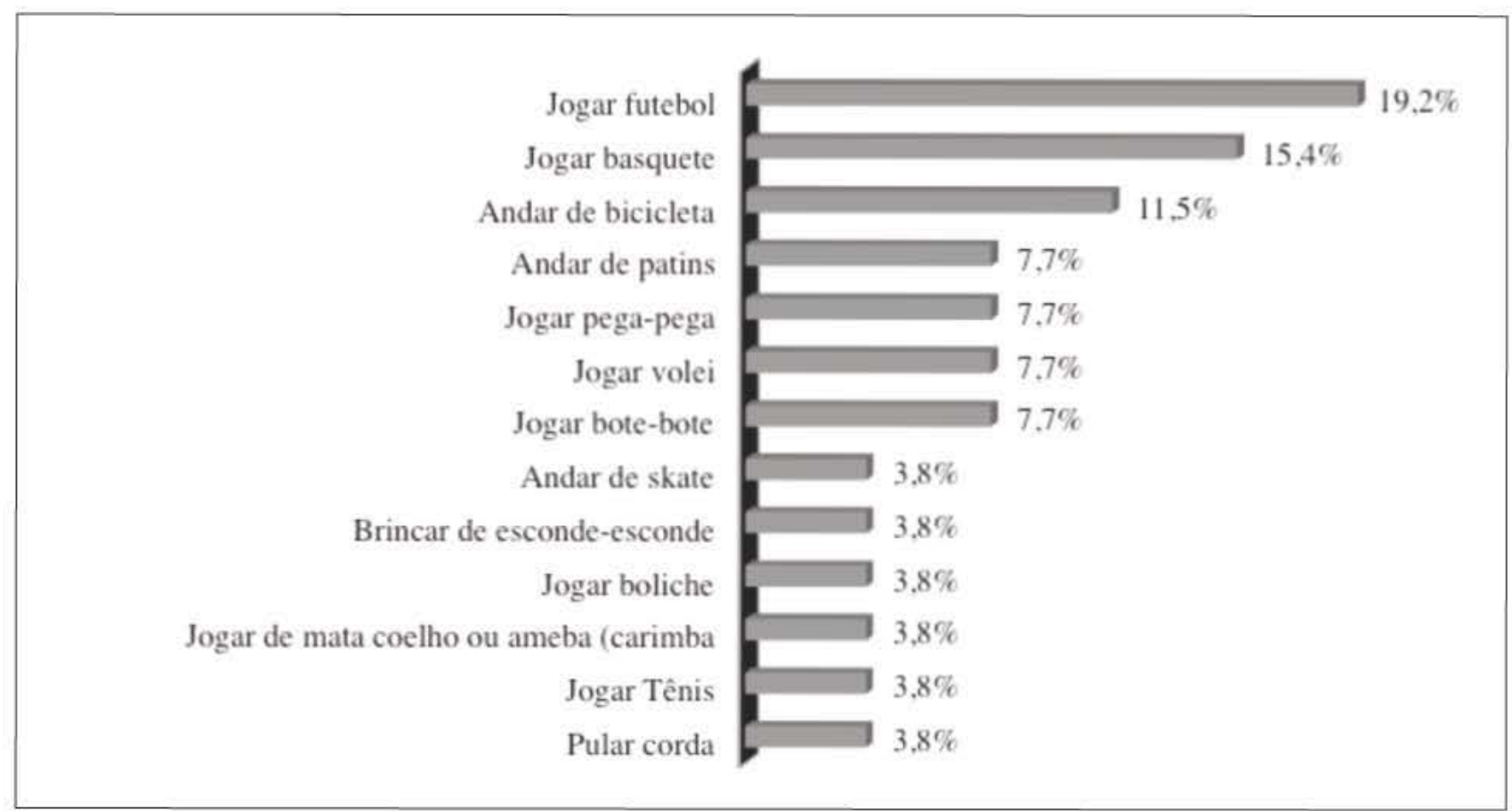

Fonte: Almeida, M.T.P., (2012).

Figure 7. Games and Play: Josep Pallach Square

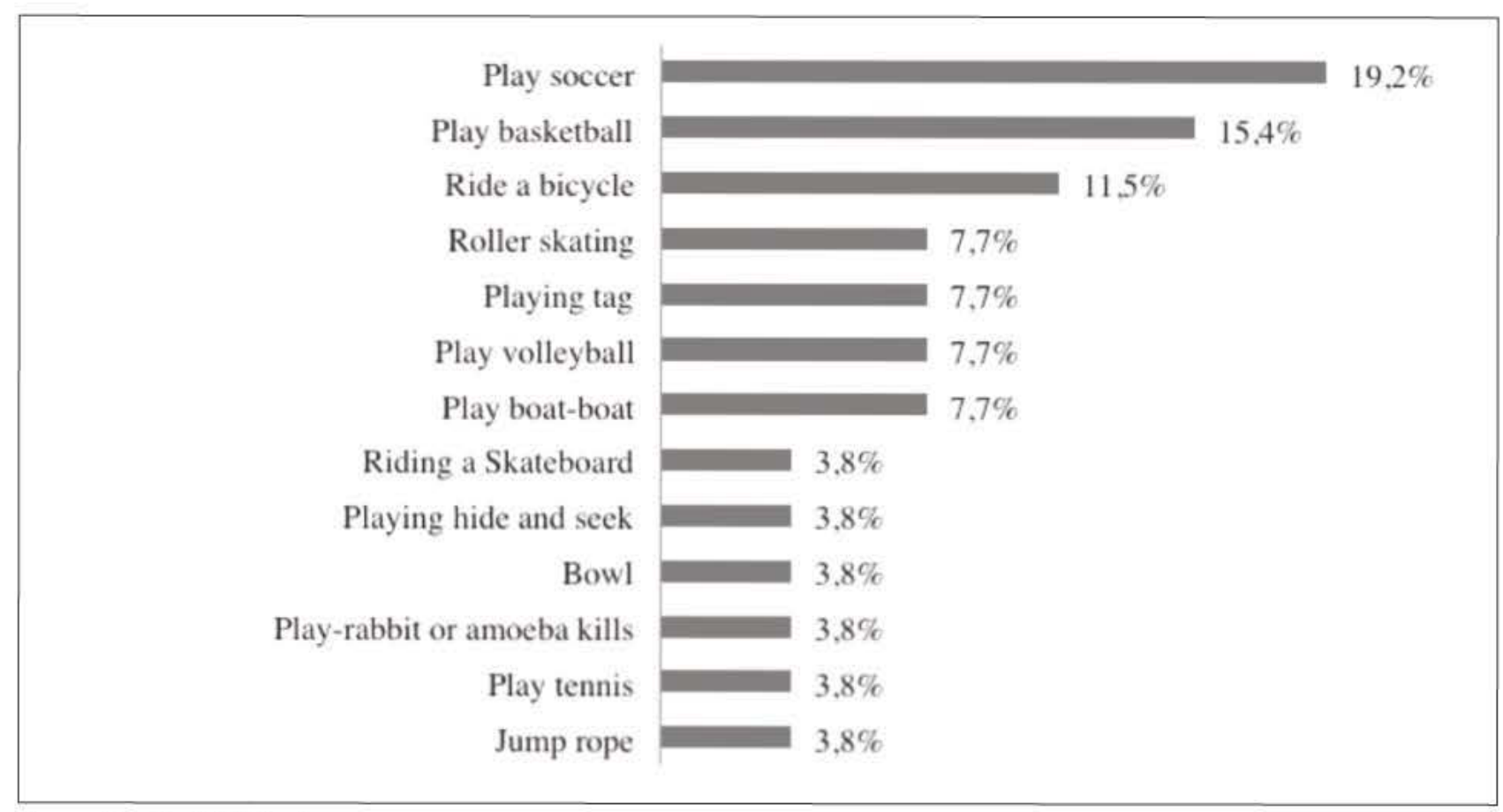

Source: Almeida, M.T.P., (2012)

opções mais atuais de equipamentos eletrônicos ou brinquedos eletrônicos, sendo referências de uma concepção mais tecnológica na vida das crianças. Era bastante comum, na fase de observação, ver crianças, jovens e adultos com seus notebooks, videogames, etc.
Finally, we analyzed the frequency of games and activities most cited by the subjects investigated in the squares. Considering the data as a whole are the following results for the first six favorite games for kids and preteens: 1st Place: Soccer; 2nd Place: Tag; 3rd Place: Boat-boat; 4th Place: Cycling; 5th Place: 
Figura 8. Brinquedos: Praça Josep Pallach

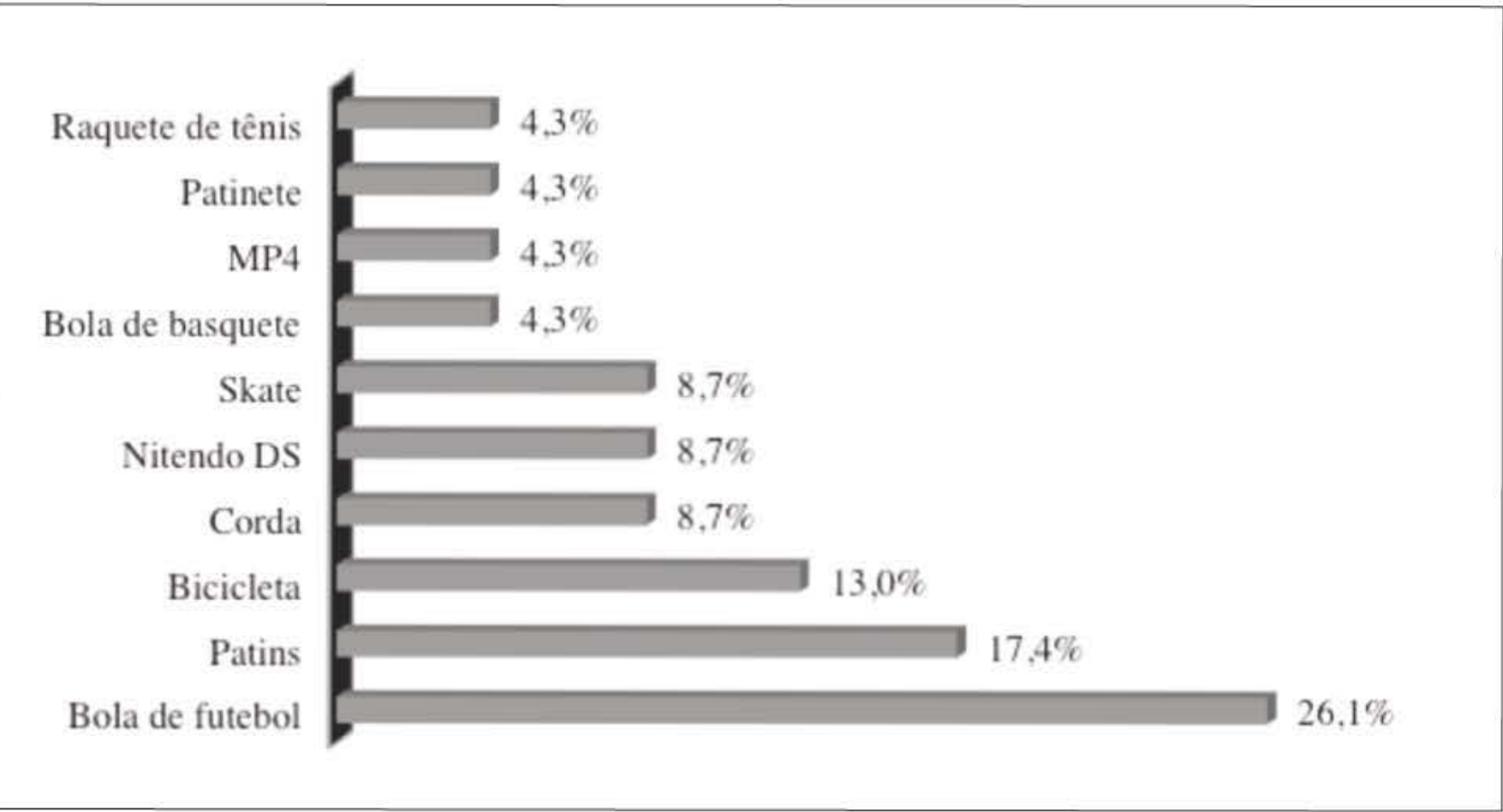

Fonte: Almeida, M.T.P., (2012).

Figure 8. Brinquedos: Praça Josep Pallach

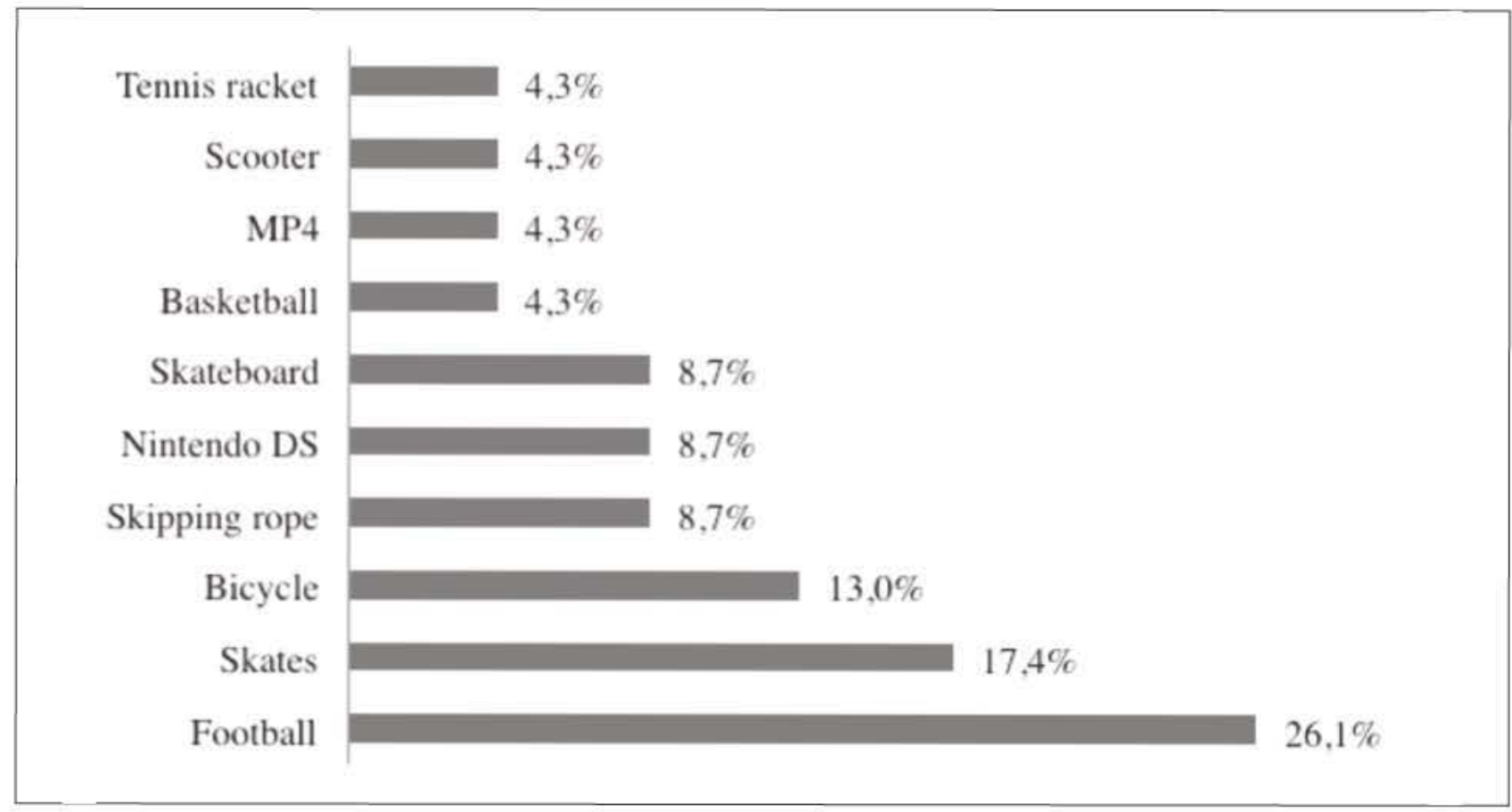

Source: Almeida, M.T.P. (2012) 
Para finalizar, analisamos a frequência dos jogos e brincadeiras mais citados pelos sujeitos investigados em cada praça pública e, considerando os dados como um todo encontram-se os seguintes resultados relativos aos seis primeiros jogos e brincadeiras preferidos pelas crianças e pré-adolescentes: 10 Lugar: Jogar futebol; 20 Lugar: Pega-pega; 30 Lugar: Botebote; $4^{\circ}$ Lugar: Andar de bicicleta; $5^{\circ}$ Lugar: Andar de patins, esconde-esconde e jogar vôlei; 60 Lugar: Pular corda.

O Jogar futebol, em todas as praças, foi o ato lúdico motriz preferido por meninas e meninos. Nas praças era bastante comum ver meninas jogando futebol com os meninos. A democratização da prática lúdica elimina barreiras de gênero, cor, raça, classe social ou religião nestes espaços públicos. Fica evidente que através do brincar é possível estimular a participação, a igualdade e a tolerância, o futebol usa a bola e o corpo como seu brinquedo motriz, com a bola criam-se pontes e caminhos e com o corpo, se vive, se pensa, se sonha e se brinca. Jogando futebol na praça as crianças resolviam suas diferenças, seus problemas e conflitos por vias não violentas.

$\mathrm{Na}$ frequência dos brinquedos mais citados nos questionários aplicados às crianças, confirma-se que a bola de futebol, os patins, a bicicleta e o skate são os brinquedos preferidos das crianças para brincar na praça. Estes brinquedos (ou objetos lúdicos) têm como característica comum estimular a prática dos jogos motrizes de habilidades e destreza, além de propor desafios tanto individual como coletivo, sendo materiais lúdicos que estão presentes nos jogos dos dois gêneros, meninas e meninos.

3.2.3. Sobre as manifestações lúdicas e de lazer e inter-relações dos usuários no espaço público

No espaço público pode-se encontrar um cenário perfeito para fazer intercâmbios de conhecimentos e compartilhar experiências intergeracionais.

$\mathrm{Na}$ Praça Joan Cornudella para a pergunta "Quem brinca mais com você" obteve-se o seguinte resultado: a. Papai e mamãe (28,6\%); b. Papai (14,3\%); c. Mamãe (0,00\%); d. Nenhum dos dois (57,1\%). Aqui se percebe que a maioria não tem os pais presentes nas atividades lúdicas que desenvolvem nesta praça.
Roller skating, hide and seek and volleyball; 6th Place: Jumping Rope.

Soccer, in all squares, was the motor skill playful act preferred by girls and boys. In the squares it was quite common to see girls playing soccer with the boys. The democratization of playful practice eliminates barriers of gender, color, race, social class or religion in these public spaces. It is evident that through playing can encourage participation, equality and tolerance. Soccer uses the ball and the body as its motor toy, with the ball we create bridges and roads and with the body, we live, we think, we dream and joke. While playing soccer in the square children settled their differences, and their problems and conflicts through non-violent ways.

The frequency of toys most cited in the questionnaires administered to the children, confirmed that the soccer balls, skates, bicycles and skateboards are the children's favorite toys to play with in the square. These toys (recreational or objects) have a common characteristic stimulate the practice of motor skills games and dexterity, and propose challenges both individually and collectively, and are materials that are present in the games of both genders, girls and boys.

3.2.3. On recreational and leisure events and interrelationships of users in public spaces

In public space we can find the perfect setting to exchange knowledge and experiences intergenerational.

In the Joan Cornudella Square to the question "Who plays with you anymore" yielded the following results: a. Mom and Dad (28.6\%); b. Dad (14.3\%); c. Mom (0.00\%); d. Neither (57.1\%). Here it is noticed that most do not have parents present in recreational activities that develop in this square. 
$\mathrm{Na}$ Praça Joseph Pallach a resposta à mesma pergunta "Quem brinca mais com você" obteve o seguinte resultado: a. Papai e mamãe (71,4\%); b. Papai (14,3\%); c. Mamãe (0,00\%); d. Nenhum dos dois (14,3\%).

Causou muita surpresa neste estudo que nos resultados nestas duas praças a opção Mamãe não tenha sido contemplada, demonstrando a ausência das mães na vida lúdica dos seus filhos nesses espaços. É importante considerar que alguns sujeitos que responderam ao questionário eram filhos de pais separados. A mãe era a responsável em manter a família financeiramente e cuidar de tudo na casa. Talvez a ausência no brincar seja justificada pelo fato de não ter tempo e não poder estar com seus filhos.

$\mathrm{Na}$ Praça Jardines de Can Brasó para a pergunta "Quem brinca mais com você" obteve-se o seguinte resultado: a. Papai e mamãe (50\%); b. Papai $(23,1 \%)$; c. Mamãe (15,14\%); d. Nenhum dos dois (11,5\%).

Observa-se nos resultados a participação significativa do pai como o representante da família que teve maior presença no brincar infantil. A figura do pai foi marcante nas respostas dos sujeitos. Durante as observações de campo, foi possível constatar que era bastante comum ver nas praças pais brincando com seus filhos. Além disso, o tempo de permanência da interação lúdica era bastante demorado (variando entre 30 a 60 minutos).

No estudo confirma-se a predominância da participação dos pais em conjunto nas atividades desenvolvidas, como se pode observar nos resultados das Praças Josep Pallach e Jardines de Can Brasó. Brincar com os pais continua sendo no imaginário infantil a melhor opção lúdica.

As relações entre as crianças maiores ou préadolescentes se estabelecem de maneira hierárquica e os usos do espaço e de seus equipamentos são definidos e controlados por elas. Os intervalos de tempo em que usam a praça são diferentes das crianças menores, estas últimas estão mais sujeitas ao controle e definição de pais e responsáveis.

Para pré-adolescentes brincar possui outro significado. O local foi apropriado para o lazer principalmente por estes grupos e seus usos são determinados pela liberdade de escolha. No questionário sobre o brincar tem-se outros resultados importantes e que ajudam a compreender melhor o significado do brincar no contexto infanto-juvenil e em especial seu próprio olhar sobre ele.
Joseph Pallach Square in response to the same question "Who plays with you anymore" obtained the following results: a. Mom and Dad (71.4\%); b. Dad (14.3\%); c. Mom (0.00\%); d. Neither (14.3\%).

What caused much surprise in these two squares was that the Mommy option has not been considered, demonstrating the absence of mothers in their children's lives playful in these spaces. It is important to consider that some subjects who answered the questionnaire were children of separated parents. The mother was responsible for keeping the family financially and take care of everything at home. Perhaps the absence in play is justified by the fact of not having time and not able to be with their children.

In the Jardines de Can Brasó Square, to the question "Who plays with you anymore" yielded the following results: a. Dad and Mom (50\%); b. Dad (23.1\%); c. Mom (15.14\%); d. Neither (11.5\%).

The results show the meaningful participation of the father as representative of the family was mostly present in the children's play. The father was striking in the responses of the subjects. During field observations, it was found that it was quite common to see the parents playing with their children. Furthermore, the interaction time was quite long (between 30 to 60 minutes).

The study confirms the predominance of parental participation in the activities developed together, as can be seen in the results of Josep Pallach and Jardines de Can Brasó Squares. Playing with parents in childhood imagination remains the best option playful.

The relationship between the older children and preteens are established in a hierarchical manner and uses of space and its equipment are defined and controlled by them. The time intervals using the square are different from younger children, the latter are more subject to the control and definition of parents and guardians.

For preteens playing has another meaning. The site was suitable for leisure especially for these groups and their uses are determined by the freedom of choice. In the questionnaire about play other important results help to better understand the significance of play in the juvenile context, and particularly their own look about him.

When we asked the subjects "with whom they like to play with", the option "play with friends" had 
Quando perguntamos para os sujeitos investigados "Com quem ele gosta de brincar", o "brincar com os amigos" teve nas três praças um resultado bastante significativo, Praça Jardines de Can Brasó e Joan Cornudella ambas com $100 \%$ e a Praça Josep Pallach com $75 \%$.

Foi confirmado na pesquisa que brincar em grupo junto dos amigos é a opção preferida pelos respondentes das Praças Josep Pallach com 75\% e Praça Jardines de Can Brasó com 55,6\%. Na Praça Joan Cornudella a opção "Depende do tipo de jogo" destaca-se com $71,4 \%$, fator possivelmente passível de ser atribuído ao fato de que a maioria dos sujeitos era pré-adolescente.

No item do questionário que perguntava "onde costuma brincar", verificou-se que a opção "Na praça pública" teve uma representação bastante positiva nas respostas das crianças e pré-adolescentes nas praças "Joan Cornudella" e "Jardines de Can Brasó", ambas com 74,1\%. Diferentemente da praça "Josep Pallach" cuja opção "Na praça pública" obteve 100\% da preferência das crianças.

Através das observações não-participantes descobrimos as preferências mais significativas de horários em que as crianças e pré-adolescentes gostam de brincar nas três praças: no período letivo, final de tarde a partir das 17:00 h, quando saem da escola, até às 20:00 h; no verão das 08:00 às 11:00 h e das 16:00 às 21:00 h; no inverno das 17:00 h às 19:00 h. O período do ano de maior apropriação das praças é o verão (período das férias escolares). Os dias da semana preferidos para brincar: sexta-feira depois da aula, sábado pela manhã e à tarde e no domingo pela manhã. Todas as crianças que frequentavam as praças "Jardines de Can Brasó", "Joan Cornudella" e "Josep Pallach", responderam Sim à pergunta "Você Brinca?" correspondendo 100\%. Brincar faz parte da vida de cada uma delas, e que em um determinado momento do dia elas vivenciam o ato de brincar.

\section{Considerações Finais}

As diferentes relações da cultura infanto-juvenil com os espaços da cidade e suas singulares relações sociais remetem àquilo que pode ser apontado como uma das características da cidade: a diversidade cultural (Torres, 1996). No estudo aqui realizado per- in the three squares a very significant result, Jardines de Can Brasó and Joan Cornudella both 100\% and Josep Pallach with $75 \%$.

Was confirmed in the study that play together with friends in group is the preferred option by respondents of Josep Pallach Square with 75\% and Jardines de Can Brasó Square with 55.6\%. On the Joan Cornudella Square "It depends on the game type" option stands out with $71.4 \%$, a factor that can be possibly attributed to the fact that most of the subjects were prepubescent.

In the questionnaire item that asked "Where jokingly," we found that the "In the public square" had a very positive representation in the responses of children and preteens in "Joan Cornudella" and "Jardines de Can Brasó" squares, both with 74.1\%. In "Josep Pallach" Square the option "In the public square" obtained $100 \%$ of the preference of the children.

Through non-participants observations we found the most significant preferences for times when children and preteens love to play in the three squares: the semester, late afternoon from 17:00, when they leave school, to the 20:00; in summer from 08:00 to 11:00 and 16:00 to 21:00; in winter from 17:00 to 19:00. The period of greater ownership of the squares is the summer (during school vacations). Preferred day of the week to play: Friday after school, Saturday morning and afternoon and Sunday morning. All children attending the squares "Jardines de Can Brasó", "Joan Cornudella" and "Josep Pallach", answered Yes to the question "Do you play?", corresponding to $100 \%$. To play is part of life of each one, and they experience the act of playing at certain time all days.

\section{Final Considerations}

The different relationships of children's culture with the spaces of the city and its unique social relations refer to what can be considered one of the characteristics of the city: cultural diversity (Torres, 1996). In the study conducted here, it perceive the plura- 
cebemos a pluralidade e diversidade de ações lúdicas realizadas e vividas pelos usuários nas praças públicas pesquisadas durante seu tempo livre na prática do lazer. As crianças e pré-adolescentes nestes espaços públicos demonstram-se criativas e livres, vivenciando diferentes formas de brincar nos espaços públicos.

Confirmou-se neste estudo que as praças pesquisadas em Barcelona, são ambientes urbanos públicos apropriados pelos habitantes, em especial pela população infanto-juvenil. Na praça esta população desenvolve diversas atividades de lazer e brinca de modo efetivo, através do jogo espontâneo ou jogo livre. Nas praças estudadas Jardines de Can Brasó, Joan Cornudella e Josep Pallach a população infanto-juvenil valoriza: os espaços mais amplos para brincar; os companheiros para brincar; situações lúdicas que potencializem suas competências motrizes; a duração do ato lúdico; espaços ou áreas para brincar com segurança e autonomia; o brincar como seus familiares (pai, mãe, avós, etc.) e outros adultos; as ações lúdicas espontâneas; a inclusão, diversidade e o pluralismo das diferentes manifestações lúdicas.

Os espaços públicos tornam-se assim o palco do desenvolvimento de ações lúdicas coletivas e/ou individuais, expressão de uma cultura geracional, intergeracional e intercultural específicas. Nesse sentido, as praças públicas objeto deste estudo assumem um significado de iniciação da criança na vida social. A praça ou a rua afirmam-se com um espaço de transição e de conexão, entre os espaços privado doméstico representado pela casa, e a cidade, com características mais amplas de espaços e esfera pública por excelência.

A publicação State of the World's Cities Report em 2012/2013 pela ONU-Habitat, cujo título é "Prosperity of cities" (prosperidade das cidades) convoca todos para discutir e refletir sobre o futuro das cidades dentro de uma perspectiva de prosperidade compartilhada e holística. A cidade tem uma força vibrante e poderosa para o desenvolvimento, ela exerce um impacto importante no bem-estar de todos do nível global ao local. Temos que reafirmar a própria essência histórica das cidades como um local onde seres humanos encontram a satisfação das necessidades básicas e acesso aos bens públicos fundamentais. E o lazer e o brincar são necessidades lity and diversity of recreational actions performed and experienced by children and preteens in the public squares surveyed during their free time at leisure practice. Children and preteens in these public spaces demonstrated creativity and freedom, experiencing different ways of playing in public spaces.

It was confirmed in this study that surveyed squares in Barcelona are public urban environments appropriated by people, especially by children and adolescents. In the square this population develops various leisure and sports activities effectively through spontaneous play or free play. In studied squares Jardines de Can Brasó, Joan Cornudella and Josep Pallach the juvenile population appreciates: the larger play spaces; mates to play; activities that enhance their motor skills; the duration of the playful act; spaces or play areas with safety and autonomy; play with their family members (father, mother, grandparents, etc.) and other adults; spontaneous playful actions; inclusion, diversity and pluralism of different recreational events.

Public space thereby become the place of development of collective and/or individual expression of a intercultural, generational and intergenerational culture. In this sense, the public squares object of this study assume a meaning of initiation of the child in social life. The square or street assert themselves with a space of transition and connection between domestic private spaces represented by the house and the town, with wider spaces and features of the public sphere par excellence.

The State of the World's Cities Report 2012/2013 published in the UN-Habitat, titled "Prosperity of cities" (prosperous cities) invites everyone to discuss and reflect on the future of cities within a shared perspective of prosperity and holistic. The city has a vibrant and powerful force for development, it has an important impact on the welfare of all the global to local. We must reaffirm the historical essence of cities as a place where humans are meeting basic needs and access to basic public goods. And leisure and play are basic necessities for any human being is a child or young person, adult or elderly. We have to think of a new kind of city in the twenty-first century, a "good living" city, a city focused on people (the human), capable of integrating tangible and in-

[ 196 ] MARCOS TEODORICO PINHEIRO DE ALMEIDA, LÚCIA MARIA GONÇALVES SIEBRA SIPS - PEDAGOGIA SOCIAL. REVISTA INTERUNIVERSITARIA [1139-1723 (2015) 25, 173-199] TERCERA ÉPOCA 
básicas para qualquer ser humano seja a criança, o jovem, o adulto ou idoso. Temos que pensar em um novo tipo de cidade no século XXI, uma cidade "boa de viver", uma cidade centrada nas pessoas (no humano), capaz de integrar os aspectos tangíveis e intangíveis da prosperidade coletiva. Uma cidade com uma maior provisão de bens públicos, com mais espaços criativos para a imaginação e interação social.

Para nós o lugar importa muito. Não podemos mais nos dar o luxo de fazer planejamentos urbanos como se o lugar não fosse importante para nossas vidas. O nosso futuro vai depender de como pensamos o futuro de nossas cidades, e em especial, como planejamos e estruturamos os espaços ou ambientes para que as crianças e jovens vivam suas interações lúdicas e manifestações de lazer.

O espaço público é o lugar do pleno exercício da cidadania e do convívio intergeracional. Nele as crianças e pré-adolescentes aprendem a conviver, brincar, disputar e compartilhar, desenvolvendo suas potencialidades físicas e emocionais. Ali também os jovens se encontram, conversam, jogam, planejam a vida. Os adultos acompanham os filhos, criam laços com outros pais, convivem com vizinhos. Os idosos fazem suas caminhadas, tomam sol, passeiam com os cachorros, encontram os amigos. O espaço público é o lugar de todos e de cada um, nele se aprende a dividir e compartilhar, a respeitar as diferenças e necessidades de cada um, se aprende enfim a conviver. tangible aspects of collective prosperity. A city with a higher provision of public goods, more creative for imagination and social interaction spaces.

For us the place matters a lot. We can no longer afford the luxury of doing urban planning as if the place was not important to our lives. Our future depends on how we think the future of our cities, and in particular how we plan and structure spaces for children and young people that permit to live their play interactions and expressions of pleasure.

Public space is the place of full citizenship and intergenerational interaction. Him children and preteens learn to socialize, play, compete and share, developing their physical and emotional potential. There also young people meet, chat, play, plan to life. Adults accompanying children, create bonds with other parents, living with neighbors. The elderly make your walks, sunbathe, stroll with the dogs, find friends. Public space is the place of all and of each individual, it is learned to divide and share, to respect the differences and needs of each, we learn at last to live.

\section{REFERENCIAS BIBLIOGRÁFICAS/ BIBLIOGRAPHIC REFERENCES}

Almeida, M. T. P. (2012). O brincar das crianças em espaços públicos. España - Barcelona: Universidad de Barcelona: 2012. 609 p. (Tese de Doutorado). Versão em Português. Depósito legal: B.33213-2012

Almeida, M. T. P. \& Siebra, L. M. G. (2008). Apropriação dos espaços públicos destinados (ou não) ao lazer infantil em um bairro residencial de Barcelona. In: $\rceil^{a}$ Congresso Internacional em Estudos da Criança. Comunicação, 2, 3 e 4 de fevereiro. Braga-Portugal: Universidade de Minho-IEC.

Almeida, M. T. P. (2000). Os Jogos tradicionais infantis em brinquedotecas Cubanas e Brasileiras. (Dissertação de Mestrado, Universidade de São Paulo - USP/PROLAM), $360 f$.

Aragonés, J. I. \& Amérigo, M. (1998). Psicología Ambiental. Madrid: Ed. Pirâmide.

Bogdan, R. \& Biklen, S. (1994). Investigação qualitativa em educação: uma introdução à teoria e aos conteúdos. Porto: Porta Editora.

Busquets, J. (2004). Barcelona: la construcción urbanística de una ciudad compacta. Barcelona, Ediciones del Serbal.

Caiuby, S. (org.) (1983). Habitações Indígenas. São Paulo: NOBEL, EDUSP. 
De Masi, D. (2001). O ócio criativo. Rio de Janeiro: Sextante.

Debortoli, J. A.; Martins, M. F. \& Martins, S. (Org.) (2008). Infâncias na Metrópole. Belo Horizonte, MG.: Editora UFMG.

Dumazedier, Joffre. (1994). A revolução cultural do tempo livre. Studio Nobel/SESC: São Paulo.

Gomes, A. M. R. \& Gouvea, M. C. S. (2008). A criança e a cidade: entre a sedução e o perigo. In: José A. Oliveira. Martins, Maria de F. Almeida \& Martins, Sérgio. (org.). Infâncias na Metrópole. Belo Horizonte: Editora UFMG. pp. 47-69.

Günther, H. \& Rozestraten, R. J. A. (2005). Psicologia Ambiental: Algumas Considerações sobre sua área de Pesquisa e Ensino. Laboratório de Psicologia Ambiental: Série Textos de Psicologia Ambiental, no 10.

Gutton, P. (2013). O brincar da criança: estudo sobre o desenvolvimento infantil. Petrópolis, RJ: Editora Vozes.

Lynch, K. (1998). La Imagen de la Ciudad. Barcelona: Editorial Gustavo Gili.

Martins, G.. (1994). Manual para elaboração de monografias e dissertações. São Paulo: Atlas.

Martínez, J.B. (1990). El estudio de casos en la investigación educativa. In Martínez, J.B. Hacia un enfoque interpretativo de la enseñanza. Granada: Universidad de Granada.

Mattar, F. N. (1996). Pesquisa de marketing. Edição compactada. São Paulo: Atlas.

Maxwell, J. A. (1996). Qualitative research design. An interactive Approach. Sage Publications.

Maykut, P. \& Morehouse, R. (1999). Investigación cualitativa. Una guía pràctica i filosófica. Barcelona: Hurtado Ediciones.

Merriam, S. (1988). Case study research in education. A qualitative approach. San Francisco: Jossey-Bass.

Neves, J. L. (1996). Pesquisa Qualitativa: características, usos e possibilidades. Caderno de Pesquisa em Administração. São Paulo, V.1, no 03, 20 Sem.

Puig, J. M. (2004). A pedagogia do Ócio. Trad. Valério Campos. 2a ed. Porto Alegre: Artmed.

Remesar, A. (1997). Para una teoría del Arte Público. Memoria para el Concurso de Cátedra.

Retondar, J.J.M. (2007). Teoria do Jogo: a dimensão lúdica da existência. Petrópolis, RJ: Editora Vozes.

Rolim, L.C. (1989). Educação e lazer - aprendizagem permanente. São Paulo: Editora Ática.

Santos, M. W. (2013). Quilombolas e o lúdico: elementos constitutivos de uma educação das relações étnicoraciais. In: Abramowicz, Anete \& Vandenbroeck, Michel. (orgs.). Educação infantil e diferença. Campinas, SP: Papirus.

Yin, R.K. (2001). Estudo de caso: planejamento e métodos. 2a ed. Porto Alegre: Bookman.

Valera, S. (1999). Espacio Privado, espacio público: dialécticas urbanas y construcción de significados. Tres al Cuarto, 6, 22-24.

[ 198 ] MARCOS TEODORICO PINHEIRO DE ALMEIDA, LÚCIA MARIA GONÇALVES SIEBRA

SIPS - PEDAGOGIA SOCIAL. REVISTA INTERUNIVERSITARIA [1139-1723 (2015) 25, 173-199] TERCERA ÉPOCA 
Pinheiro de Almeida, M.T. \& Gonçalves Siebra, L.M. (2015). O lazer infanto-juvenil nos espaços públicos de Barcelona. Pedagogía Social. Revista Interuniversitaria, 25 173-199. doi:10.7179/PSRI_2015.25.8

Fecha de recepción del artículo / received date: 24.VI.2O14

Fecha de revisión del artículo / reviewed date: 26.VI.2014

Fecha de aceptación final / accepted date: 21.X.2014

\section{DIRECCIÓN DE LOS AUTORES/ AUTHORS' ADDRESS:}

Marcos Teodorico Pinheiro de Almeida y Lúcia Maria Gonçalves Siebra

Rua Vicente Linhares 1301 apto 1602 - Bairro Aldeota - CEP: 60.135-270 - Fortaleza - Ceará - Brasil

Dirección de correo/e-mail: mtpa@ufc.br; luciasiebra@gmail.com

PERFIL ACADÉMICO / ACADEMIC PROFILE:

Marcos Teodorico Pinheiro de Almeida. Professor do Instituto de Educação Física e Esportes (IEFES) da Universidade Federal do Ceará (UFC). Doutor em Pedagogia pela Universidade de Barcelona (UB). Mestre em Educação pela Universidade de São Paulo (USP). Graduado em Educação Física pela Universidade de Fortaleza (UNIFOR). Coordenador do Centro de Estudo sobre Ludicidade e Lazer (CELULA).

Lúcia Maria Gonçalves Siebra. Professora do Departamento de Psicologia da Universidade Federal do Ceará - UFC. Doutora pela Universidade de Barcelona - UB no Programa de Doutorado em Espaço Público e Regeneração Urbana: Arte, Teoria e Conservação do Patrimônio. Mestre em Administração pela Universidade de São Paulo - USP. Graduada em Psicologia pela Universidade Federal do Ceará - UFC. 
